\title{
Bed type and flow mechanism of deep water sub-lacustrine fan fringe facies: an example from the Middle Permian Lucaogou Formation in Southern Junggar Basin of NW China
}

\author{
Xin Shan ${ }^{1,2,3} \cdot$ Xing-He Yu ${ }^{2}$ Lina Jin ${ }^{2} \cdot$ Ya-Long $\mathrm{Li}^{2} \cdot$ Cheng-Peng $\mathrm{Tan}^{2} \cdot$ Shun-Li Li ${ }^{2} \cdot$ Jun-Hui Wang ${ }^{4}$
}

Received: 10 August 2020 / Accepted: 13 October 2020 / Published online: 4 December 2020

(c) The Author(s) 2020

\begin{abstract}
Submarine or sub-lacustrine lobe deposits are important reservoirs, but the fan fringe deposits form heterogeneities within deep water fan deposits. Fan fringe facies records the complex sediment gravity flow types. By understanding of the bed types and flow mechanisms, we can identify the fan fringe deposit, which aids in the reconstruction of deep water fan and reservoir evaluations. The Jiucaiyuanzi and Dalongkou sections in the West Bogda Mountains preserve well-exposed 536-m and 171-m thick successions, respectively, of a deep water lacustrine depositional system from the Middle Permian Lucaogou Formation. Bed types of the Lucaogou Formation include high-density turbidite, low-density turbidite, incomplete Boumatype turbidite, hybrid event beds, and slump deposits. The Lucaogou Formation is interpreted here as a fan fringe facies due to the thin bed thickness that characterize turbidites and hybrid event beds, as well as the predominance of the isolated sheet architecture. Previous studies suggest that these deposits were considered as deposited in a deep water setting due to the absence of wave-related structures. The presence of abundant mud clasts in massive medium-coarse grained sandstone beds reflects the significant erosional capability and interactions between high-density turbidity currents and lake floor. The fan fringe facies here contains amalgamated and thick-bedded homolithic facies $(\sim 30 \%)$ and thin-bedded heterolithic facies $(\sim 70 \%)$. The examination of the bed type is of wider significance for facies prediction and reservoir heterogeneity in the sub-lacustrine fan fringe facies.
\end{abstract}

Keywords Fan fringe $\cdot$ High-density turbidite $\cdot$ Low-density turbidite $\cdot$ Hybrid event bed $\cdot$ Lucaogou Formation $\cdot$ Junggar basin

\section{Introduction}

Handling Editor: Cheng Lin Gong

Edited by Jie Hao and Chun Yan Tang

Xing-He Yu

billyu@cugb.edu.cn

1 Key Laboratory of Marine Geology and Metallogeny, First Institute of Oceanography, Ministry of Natural Resources, Qingdao 266061, Shandong, China

2 Department of Energy Resources, China University of Geosciences (Beijing), Beijing 100083, China

3 Laboratory for Marine Geology, Pilot Qingdao National Laboratory for Marine Science and Technology, Qingdao 266061, China

4 School of Earth Sciences, China University of Petroleum (Beijing), Beijing 102200, China
Mass-flow processes deposit submarine fans, which correspond to distinct constructional sediment bodies on the sea floor that develop seaward of a major sediment point source (Normark 1978; Walker 1978; Reading and Richards 1994). Important components of the submarine fan include the submarine channels, channel-lobe transition zones, and submarine lobes. Submarine lobes, specifically, can constitute the bulk of the volume of a submarine fan (Normark 1978; Pickering 1981a, b; Piper and Normark 1983). Lobes are often incised by channels in the proximal area, the deposits of which are characterized by thick-bedded channel fills and sheets (Fildani and Normark 2004). Besides thick turbidites in the proximal lobe (lobe axis and off-axis), hybrid event beds, with a thick division in terms of the high-density turbidite (i.e., the H1 division in Haughton et al. (2009)), also occur in the proximal position (Ito 2008; Patacci et al. 
2014; Mueller et al. 2017). When compared with axial and proximal components, the fan fringe (lobe fringe and distal fringe) is an important albeit comparably overlooked paleoenvironmental setting. Sheet deposits, which are composed of thin-bedded turbidites, can be considered as fan fringe deposits (Mutti 1977). However, relatively few studies have examined the detailed bed types and flow mechanism of fan fringe deposits (Davis et al. 2009; Kane and Pontén 2012; Fonnesu et al. 2018; Pierce et al. 2018). The fan fringe and its deposits are more heterogeneous than sandier proximaland mid-submarine fans (Haughton et al. 2003; Spychala et al. 2017a, b; Brooks et al. 2018). If we are to understand reservoir heterogeneity of a fan fringe deposit, we must examine its sedimentary sequence and bed type.

In contrast to many well-documented sub-marine fan fringe deposits, there is much less information about the sub-lacustrine ones. Lacustrine sediment gravity flow deposits are probably different from marine ones, because marine environments are characterized by larger-scale depositional systems, deeper water, and a longer runout distance (Yang et al. 2019). Most sub-lacustrine fan deposits were interpreted mostly as debrites or/and turbidites, including the well-known Eocene Dongying depression and the Upper Triassic turbidites in the Ordos Basin (Zou et al. 2012; Liu et al. 2017; Yang et al. 2017, 2019). This raises the following questions. Do hybrid event beds exist in the sub-lacustrine fan fringe facies? What are bed types and transport mechanisms of sub-lacustrine fan fringe facies?

The Middle Permian Lucaogou Formation in the Junggar Basin of NW China was selected in this study, because it represents a sub-lacustrine fan fringe facies, and the deposits of which reveal the bed types, sedimentary sequences, and sedimentary processes of a fan fringe setting. Previous studies on the Lucaogou Formation have mainly focused on reservoir characteristics (Wu et al. 2016; Zhao et al. 2017; Su et al. 2018) and the tight oil potential (Kuang et al. 2012; Gao et al. 2016; Cao et al. 2016, 2017; Luo et al. 2018). However, few studies focus on bed-scale investigations and the sedimentary processes that allow the formation of these beds. This study describes the bed types and depositional architectures of deep water sub-lacustrine fan fringe deposits from the Lucaogou Formation. Bed type studies here have implications for sediment transport in a fan fringe setting and reservoir heterogeneities of the deep water lake deposits. The aims of the study are to (1) document the bed types and interpret the flow mechanism of the Lucaogou Formation; (2) describe the depositional architecture of the Lucaogou Formation and understand why the Lucaogou Formation is considered as a fan fringe facies, and (3) discuss the heterogeneities in fan fringe facies of the Lucaogou Formation.

\section{Geological setting of Southern Junggar Basin}

\subsection{Tectonic setting}

Intracontinental orogenic belts (Tianshan) and their surrounding flexural basins (the Tarim and Junggar basins) typify the tectonic settings of central Asia. To the north of the Tarim Basin, the Junggar Basin is a relatively small composite terrane that was welded to the Tarim Basin during the Devonian and Carboniferous (Charvet et al. 2007). The basin architecture is composed of a stacked accumulation of Cambrian to Permian rocks that were formed via volcanic arcs, accretionary prisms, oceanic crust obduction, and later granite intrusion (Xiao et al. 2002; Cocks and Torsvik 2013). The composition of the Carboniferous sandstone in the southern Junggar Basin indicates arc volcanism (Carroll et al. 1995). In the Permian rocks, the increased quartz and potassium feldspar in the sandstones could potentially indicate the extinction of volcanic arcs and the erosion of the Tianshan granite intrusions (Carroll et al. 1995). At the end of the early Permian, the West Bogda Trough was closed, and an island arc formed via the subduction of the Tarim Plate (Wang et al. 2018). The Bogda island arc is considered to be the sediment source of the Lucaogou Formation in Southern Junggar Basin (Wang et al. 2018). The deposition of the Lucaogou Formation occurred at middle paleolatitudes (i.e., $39^{\circ}-43^{\circ} \mathrm{N}$ ) (Nie et al. 1993).

\subsection{Paleozoic stratigraphy in the southern Junggar Basin and study area}

The oldest reported rocks exposed in the southern Junggar Basin are from Lower to Middle Carboniferous andesitic volcaniclastics that occur in deep marine settings, which are characterized by the features of sediment gravity flow deposits (Carroll et al. 1990). In Upper Carboniferous units, a regressive sequence with a thickness of $800 \mathrm{~m}$, composed of carbonates and volcaniclastic turbidites, overlies the deep water facies.

The Permian in the southern Junggar Basin is composed of lacustrine and fluvial mudstones, siltstones, and fine-grained sandstones (thicker than $2000 \mathrm{~m}$ ). The Middle and Upper Permian comprises over $1000 \mathrm{~m}$ of organic-rich lacustrine deposits (Carroll 1998). These deposits record an overall evolution from relatively shallow evaporative lakes to relatively deep lakes with the fluvial system (Carroll 1998).

At the front of Bogda Mountain, the Lucaogou Formation consists of laminated dark gray mudstone, with an approximate thickness of $900 \mathrm{~m}$, and no evidence of subaerial exposure (Carroll 1998). The average total organic carbon content (TOC) of the Lucaogou laminated facies is 
approximately $4.3 \%(S 2=26.2 \mathrm{mg} / \mathrm{g})$, and thus the Lucaogou is among the thickest and richest petroleum source rocks in the world (Carroll et al. 1992). Biomarker analysis indicates a saline to brackish depositional environment and low to moderate terrestrial organic matter input (Carroll et al. 1998). Oil shale collected from the southern Junggar contains sufficient hydrogen-rich organic matter (Kerogen Type I and II) to indicate that the shale was deposited in a clastic and algal-dominated environment (Tao et al. 2012). Fine laminae throughout the majority of the Lucaogou Formation in the Southern Junggar Basin and an absence of burrowing trace fossils and storm wave-related structures (i.e., hummocky and swaley cross-bedding) have been interpreted as deposited under anoxic conditions in water depths below the storm wave base and thereby a deep water setting (Carroll et al. 1998). Thus, organic matter particles that accumulated on the lake floor through a vertical settling regime were preserved under an anoxic and deep-lake environment (Carroll et al. 1998; Tao et al. 2012). Based on the wind fetch and wave size, estimates for the depth of Lucaogou Lake are in the range of several hundred meters (Carroll et al. 1992, 1998).

The measured sections presented in this study are located in the southern Junggar Basin (Figs. 1, 2). The Lucaogou Formation is a lacustrine deposit which comprises sandstone, siltstone, and claystone (Figs. 2, 3). The thickness of the Lucaogou Formation in the Jiucaiyuanzi and Dalongkou sections is $530 \mathrm{~m}$ and $170 \mathrm{~m}$, respectively (Fig. 3). The distance between two sections is $\sim 35 \mathrm{~km}$. The Bogda island arc is considered to be the sediment source of the Lucaogou Formation in Southern Junggar Basin (Wang et al. 2018). The direction of sediment supply of Lucaogou Formation is to the north in Junggar Basin or to the northeast in northwestern Turpan Basin (Carroll et al. 1995; Wang et al. 2018). The large difference in the thickness between the two sections is a consequence of thrust faults presented in the southern Junggar Basin (Carroll et al. 1992, 1995).

\section{Methodology and terminology}

\subsection{Synthetic example}

The stratigraphic thickness, color, sedimentary texture, and sedimentary structure of the Jiucaiyuanzi section and Dalongkou section in the Lucaogou Formation were examined and measured at areas of adequate exposure along river beds in the southern Junggar Basin, NW China (Figs. 1, 3). Strata with approximate thicknesses of $700 \mathrm{~m}$ were measured throughout two modern river valleys (Figs. 1,3). This study is based on detailed bedscale descriptions. We used a hand lens and grain-size comparator to measure grain size in the field. Besides the background laminated mudstone, a total of 385 beds were measured and examined (Table 1). The typical sedimentary logs associated with the grain size features were drawn to provide evidence of the sedimentary facies types.

We present the results from our fieldwork and organize the data relative to the lithofacies/lithofacies associations. We first describe our field observations with respect to each lithofacies/lithofacies association, followed by our interpretation of these descriptions. In the Lucaogou Formation, there are three types of lithofacies associations: turbidites, hybrid event beds, and slumps.

Fan fringe (setting) is used here as a geographic description, as well as a paleo-environmental term. Thus, the fan fringe facies refers to sediments or sedimentary rocks that accumulated in the fan fringe setting. In the fan fringe facies, the lobe and inter-lobe deposits can be distinguished based on bed amalgamation, bed thickness, lithology (mud- or sand-dominated), and sedimentary structures (Prélat et al. 2009; Spychala et al. 2017b, 2017a, b).

\section{Bed types of the deep water system in the Lucaogou Formation}

\subsection{Turbidite beds}

\subsubsection{Abundant graded or ungraded massive sandstone and space planar laminated sandstone}

4.1.1.1 Description Massive sandstone, with bed thicknesses varying from $2 \mathrm{~cm}$ to $1 \mathrm{~m}$, has a sharp base (Fig. 4ad). The light yellow or yellowish-brown, massive sandstone units can be normally graded (Fig. 4a), ranging from coarse to fine-grained sandstone. Some structureless units are graded (Fig. 4b-d). Mud clasts are commonly present in massive intervals, with a diameter ranging from several centimeters to a few decimeters (Fig. 4c, d). The mud clasts that occur along discrete horizons within the deposit (Fig. 4c, d) planar laminated deposits with coarsening- and finingupward intervals, albeit not with distinct layer boundary (which forms the base of the beds), were observed (Fig. 4e).

Occasionally, faults in the Jiucaiyuanzi Valley region terminate upward beneath the overlying planar laminated sandstone and are restricted to the single turbidite event bed (Fig. 5). Some faults are even confined within two laminae (Fig. 5). Unit thickness changes across the fault, i.e., hanging-wall thickening and footwall thinning, are characteristic (Fig. 5).

4.1.1.2 Interpretation Massive sandstone (graded or not) can be left by gradual aggradation beneath high-density turbidity currents (Kneller and Branney 1995) or deposited by 


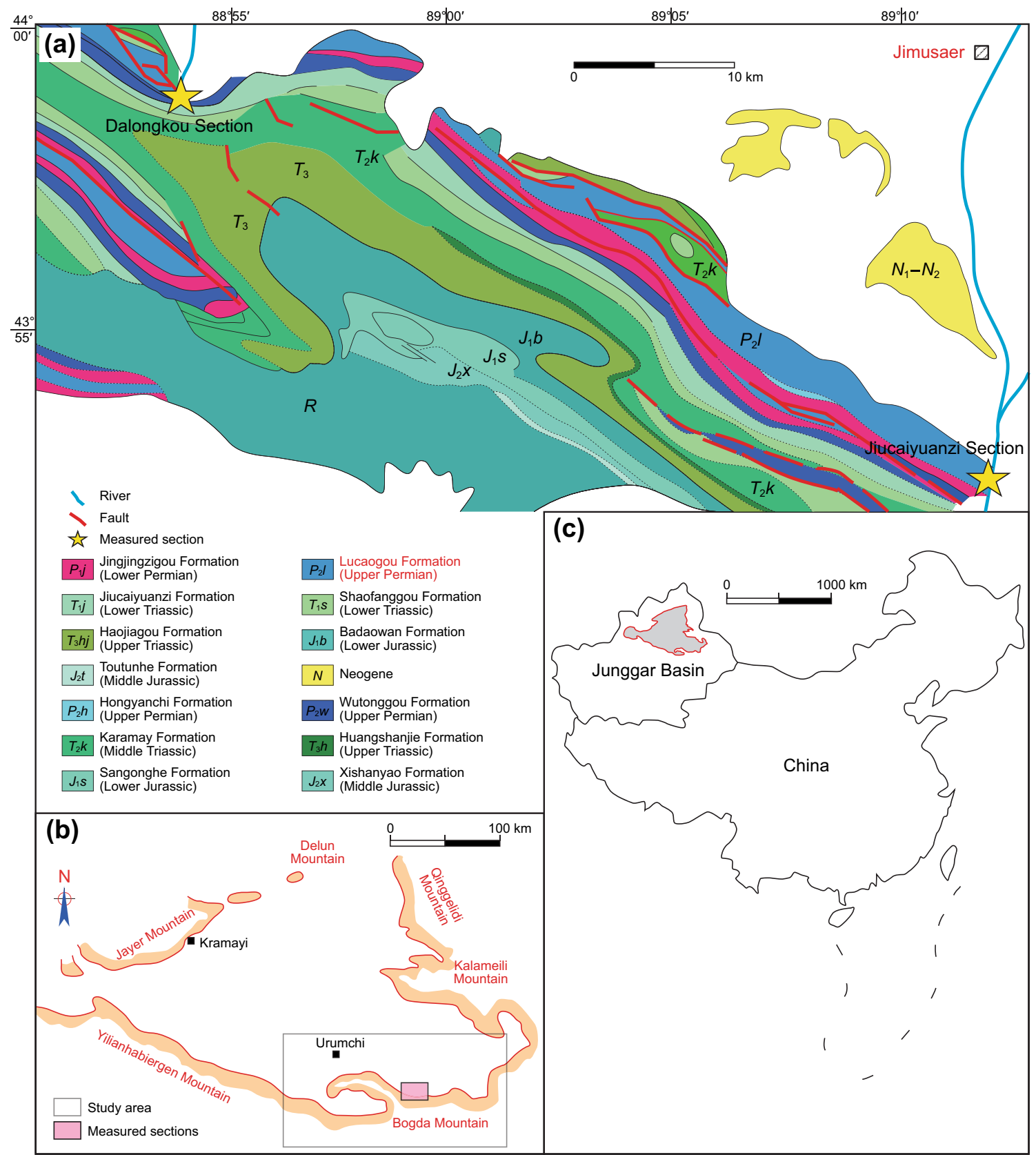

Fig. 1 Geological setting and characteristics of the southern Junggar Basin, showing the stratigraphy distribution in the study area is shown. Measured sections are the Dalongkou section and Jiucaiyuanzi section

laminar debris flows (Talling et al. 2013). The absence of bedforms within the massive sandstone suggests en masse deposition (Talling et al. 2012) or hindered settling that potentially results from high near-bed sediment concentrations (Baas et al. 2011).

The massive sandstone intervals exhibit a low matrix mud content (e.g., Fig. 4b-d) and are prevalent in coarse-grained and thicker beds that tend to occur in proximal components (Talling et al. 2012). Massive sandstone with discrete horizons of mud clasts potentially indicates deposition from traction carpets via progressive aggradation (Sohn 1997). The low matrix mud content and horizons of mud clasts of the massive sandstone here can rule out debris flow sedimentation (Talling et al. 2013). Sustained traction carpet also produces spaced planar lamination with coarsening and fining-upward intervals, albeit without a layer boundary, when the grain size of the supplied sediment varied with time (Hiscott 1994; Sohn 1997). Such stratified deposits are found in proximal settings (see Fig. 22 in Sumner et al. 2012). High-density turbidity currents likely form under 


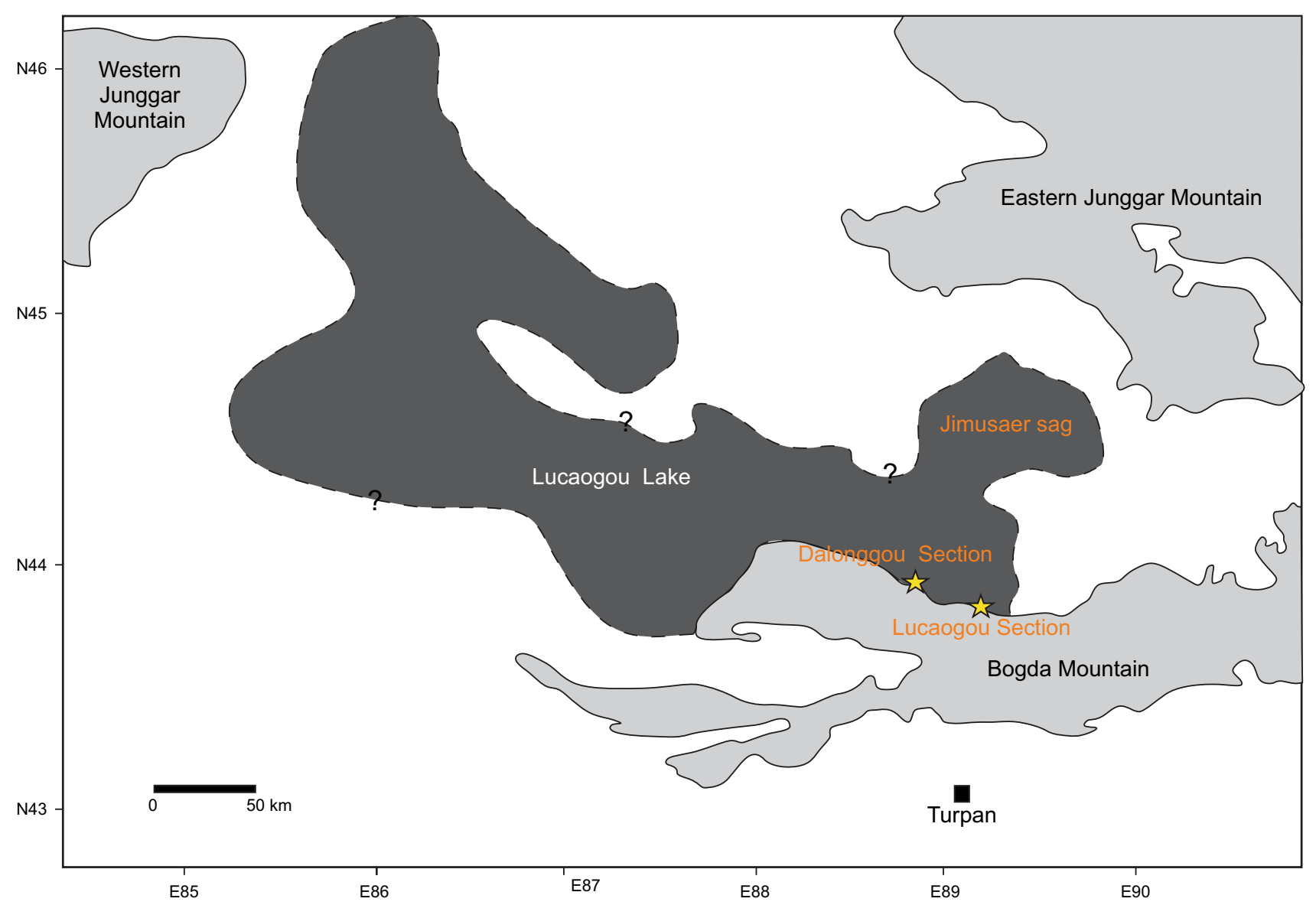

Fig. 2 Paleography of the Lucaogou Formation. The extent of Lucaogou Lake is based on Carroll and Bohacs (2001)

conditions of such higher near-bed concentrations, which leads to damping of turbulence.

Synsedimentary faults occur within one turbidite bed (Fig. 5) and thus formed during the deposition of a single flow. The pre-faulted sequence is the sedimentary package deposited prior to extension. The synfaulted sequence is composed of sediments deposited during extension (Fossen 2016). The post-faulted sequence represents sedimentation after the cessation of extension. These sequences with synsedimentary faults can more easily form due to an instability of the sediment (e.g., on a slope) coupled with the shearing of a still overriding flow (c.f. Butler et al. 2015), as opposed to an external force, such as an earthquake.

\subsubsection{Appreciable ripple cross-laminated siltstone and laminated mudstone}

4.1.2.1 Description Ripple cross-laminated, light yellow, or yellowish-brown siltstone and laminated mudstone are commonly observed in the deep water system of the Lucaogou Formation (Fig. 6). Ripple cross-laminated intervals are typically thin and range from a few $\mathrm{mm}$ to $4 \mathrm{~cm}$ in thickness (Fig. 6a-d). Laminated mudstone typically overlies ripple cross-laminated intervals (Fig. 6a-d). The thickness of a single laminated mudstone bed is less than $20 \mathrm{~cm}$. Besides current ripples, long thin bedforms with a height of 1-5 mm and length of 70-150 $\mathrm{mm}$ are commonly observed in mud-dominated successions (Fig. 6e-h). Most long-thin bedforms here are encased in siltstone or mudstone (e.g., Fig. 6h).

4.1.2.2 Interpretation Ripple cross-laminated intervals indicate fully turbulent conditions (Allen 1963, 1968; Southard 1991; Baas et al. 2011). Dilute or low-density turbidity currents exhibit this type of near-bed, fully turbulent suspension (Baas et al. 2011). The laminated mudstone described here (Fig. 6a-d) with laminations of $<2 \mathrm{~mm}$, conforms to the Te-1 division (i.e., the top division of the Bouma sequence) as proposed by Piper (1978). Specifically, the Te-1 division is deposited incrementally from dilute turbidity current (Stow and Bowen 1980). The ripple crosslaminated division overlain by laminated mudstone (Te-1), as illustrated here, suggests that the succession is formed by waning dilute flow (e.g., Fig. 6a-d; Talling et al. 2012). 

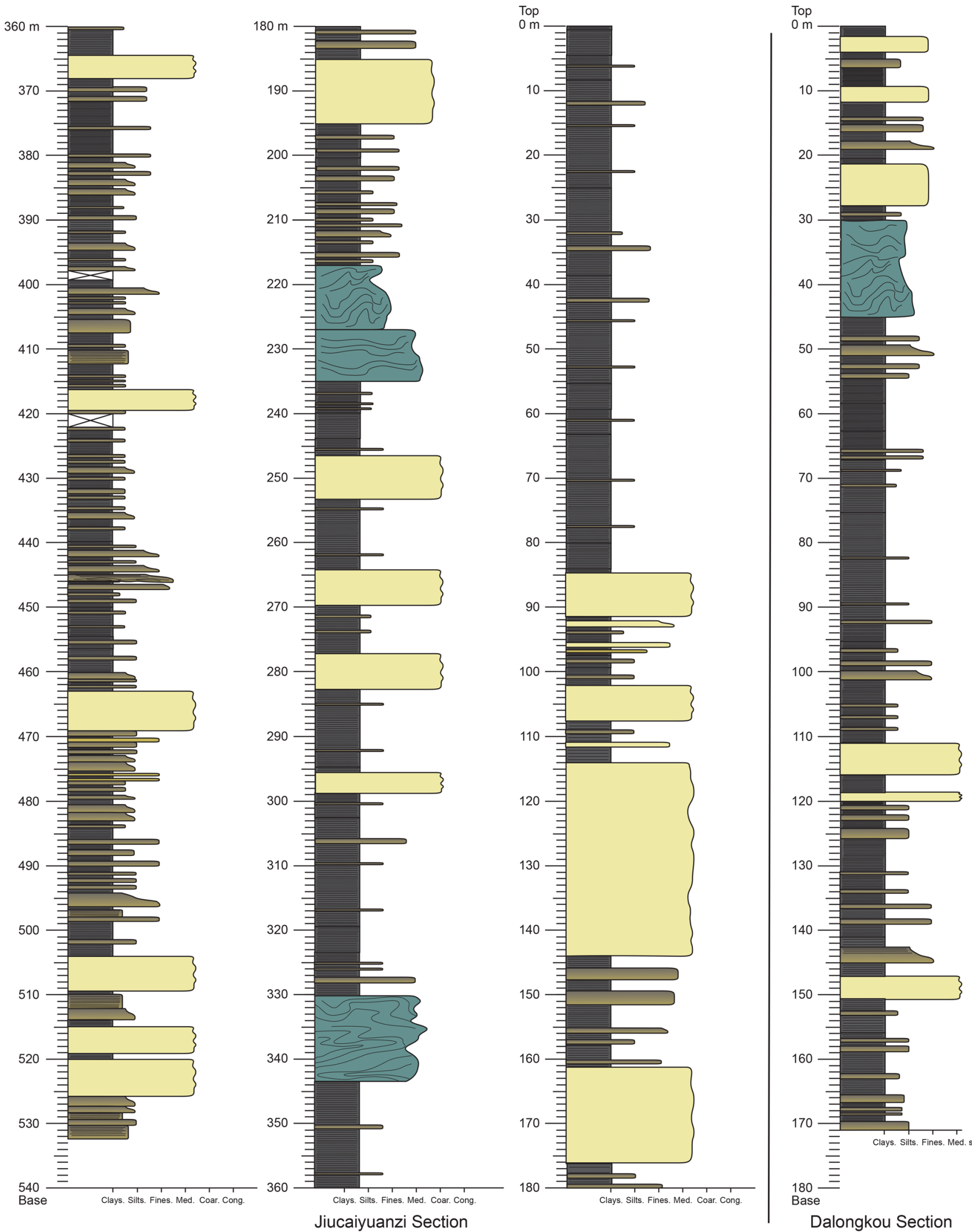

Amalgamated shee shallow channel

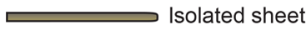

Slump deposit

Mudstone 
4 Fig. 3 Detailed measured sections of the Lucaogou Formation in the Jiucaiyuanzi section and Dalongkou section, Southern Junggar Basin (see Fig. 1 for locations). The Lucaogou Formation from the Jiucaiyuanzi section and Dalongkou section consists of sandstone, siltstone, and claystone. Some amalgamated beds and isolated beds can be observed

\subsubsection{Other turbidite bed types}

4.1.3.1 Description In addition to the turbidite bed types described in Sects. 4.1.1 and 4.1.2, two other bed types were observed. The two bed types include normal graded, massive sandstone, fine-scale planar laminated sandstone, cross-laminated sandstone from base up (Fig. 7a), or massive sandstone, spaced planar laminated sandstone, climbing-ripple cross-laminated sandstone to fine-scale planar laminated sandstone from the base to the top (Fig. 7b). In Fig. 7a, the normal graded type is coarse tail grading, which shows a gradual upward decrease in the size of the coarsest grains (see graded division in Fig. 7a). Fine planar laminations are mainly less than $3 \mathrm{~mm}$, while spaced laminations range from $5 \mathrm{~mm}$ to $3 \mathrm{~cm}$ in thickness.

Occasionally, a single grain size break occurs within the overall fining upward sequence (Fig. 7b). The overlying interval typically corresponds to ripple cross-laminated sandstone, while the underlying component comprises massive and spaced planar laminated sandstone. Small mud clasts are present along the grain size boundary, and erosional truncations (scour and fill structures) can be identified along the break. Abrupt upward reductions in grain size can be observed (Fig. 7b).

A train of asymmetric folds was commonly observed on top of the fine-scale planar bedded beds and beneath another turbidite bed (Fig. 8).

4.1.3.2 Interpretation High-density turbidity can produce spaced planar lamination and fine planar lamination (see planar laminations in Fig. 7a, b that correspond to $\mathrm{Tb}-2$ and $\mathrm{Tb}-3$ (i.e., the $\mathrm{Tb}$ division of the Bouma sequence) reported in Talling et al. 2012). Coarse-tail graded sandstone and fine planar lamination mainly reflect supercritical flow conditions (Postma et al. 2009; Postma and Cartigny 2014), whereas the cross-laminations reflect dilute current and subcritical flow conditions (Allen 1963, 1968; Postma and Cartigny 2014). Thus, the coarse-tail graded sandstone to fine-scale planar laminated sandstone to cross-laminated sandstone sequence probably indicates a waning turbidity current.

The massive sandstone to spaced planar laminated sandstone to climbing-ripple cross-laminated sandstone and fine-scale planar laminated sandstone succession (Fig. 7b) reflects an overall decrease in the flow density. Climbing ripples, which require bedload transport and concurrent rapid suspended load fallout (Jobe et al. 2012), indicate rapid sediment deposition (Allen 1991).

The grain size break described above does not record bed amalgamation from multiple flows and is only significant within one single flow deposit (Fig. 7b). The concentration gradient within the flow is significant in terms of the formation of the grain size break type (Jobe et al. 2012). To interpret this phenomenon, Gladstone and Sparks (2002) proposed a high suspended concentration basal zone overlain by an upper low concentration zone. Experiments suggest that hiatuses occurred during the formation of the break (Sumner et al. 2012). Below the break, the deposits can be attributed to a high sedimentation rate, while the rate is significantly lower above the break (Sumner et al. 2012; Stevenson et al. 2015). The change in the deposition rate is potentially related to a change that occurred in the settling regime (Kneller and McCaffrey 2003).

The asymmetric folds in Fig. 8 are interpreted as being formed by shear stress that was exerted by the overlying turbidity current. Continued passage of the turbidity current should erode the deformed bed (Butler et al. 2015).

Table 1 Beds measured at Jiucaiyuanzi section and Dalongkou section

\begin{tabular}{|c|c|c|}
\hline Section & Jiucaiyuanzi section & Dalongkou section \\
\hline Location & E89¹0'43.53", N4352'58.85" & E88 $51^{\prime} 46.132^{\prime \prime}, N^{\circ} 57^{\circ} 21.63^{\prime \prime}$ \\
\hline Beds studied & 235 & 150 \\
\hline Turbidite beds & $\begin{array}{l}\sim 150-160 \text { beds ( }>60 \% \text { of the beds except for the back- } \\
\text { ground mudstone) }\end{array}$ & $\begin{array}{l}\sim 100-110 \text { beds ( }>70 \% \text { of the } \\
\text { beds except for the back- } \\
\text { ground mudstone) }\end{array}$ \\
\hline Hybrid event beds & $\begin{array}{l}\sim 70-80 \text { beds ( } 30-35 \% \text { of the beds except for the back- } \\
\text { ground mudstone) }\end{array}$ & $\begin{array}{l}\sim 40-50 \text { beds }(25-30 \% \text { of the } \\
\text { beds except for the back- } \\
\text { ground mudstone) }\end{array}$ \\
\hline Slump deposits & 3 slump deposits & 1 slump deposits \\
\hline Background mudstone (laminated mudstone) & $80 \%$ & $85 \%$ \\
\hline
\end{tabular}



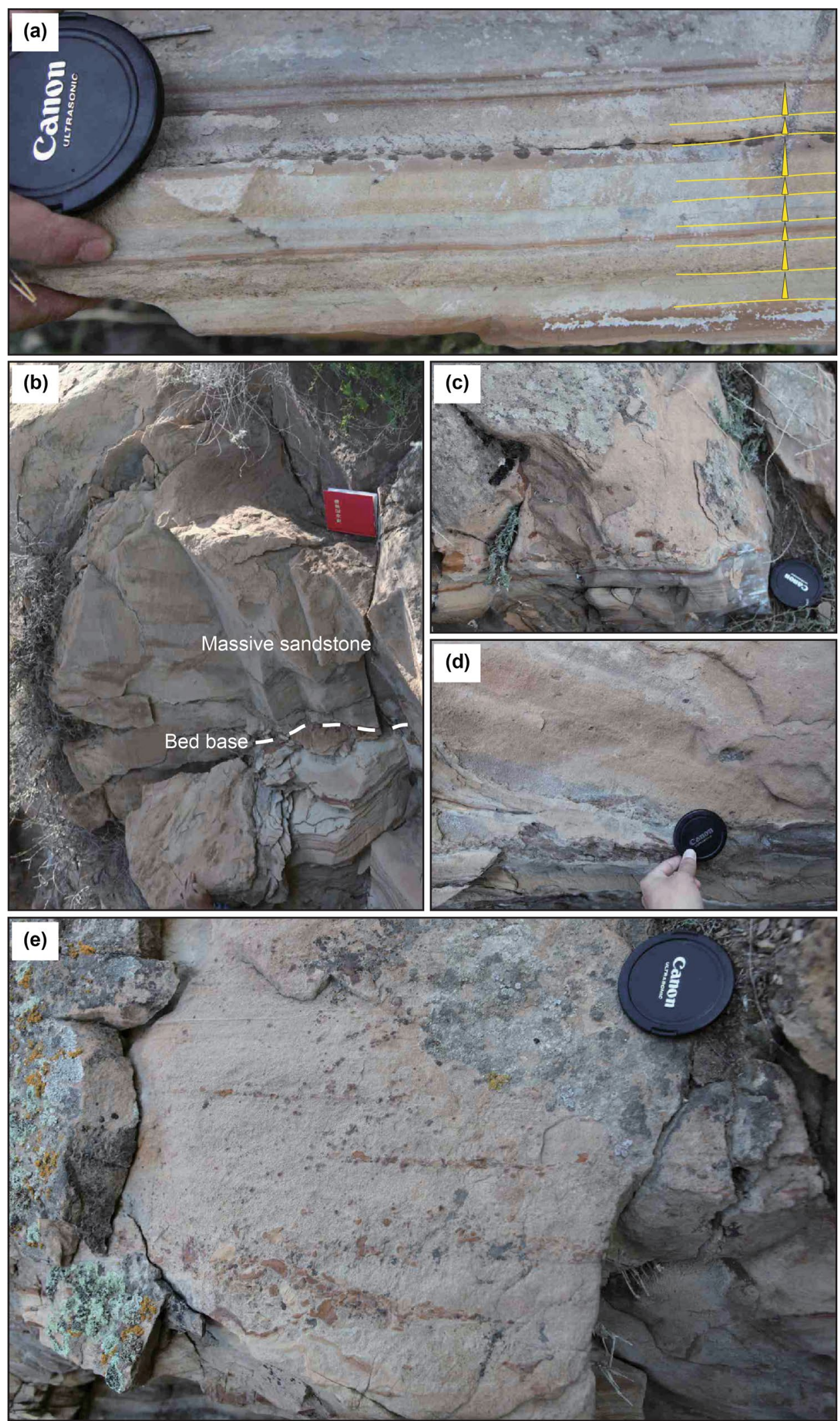

Fig. 4 High-density turbidite. a Thin-bedded turbidites with bed thicknesses of a few mms. The turbidites are normal graded, and no structures can be observed. b Massive sandstone which is interpreted as a high-density turbidite. c Massive sandstone with mud clasts. The mud clasts occurred along several horizons. d Massive sandstone with mud clasts. The mud clasts are well-rounded. e Spaced planar laminated sandstone with several horizons of mud clasts 

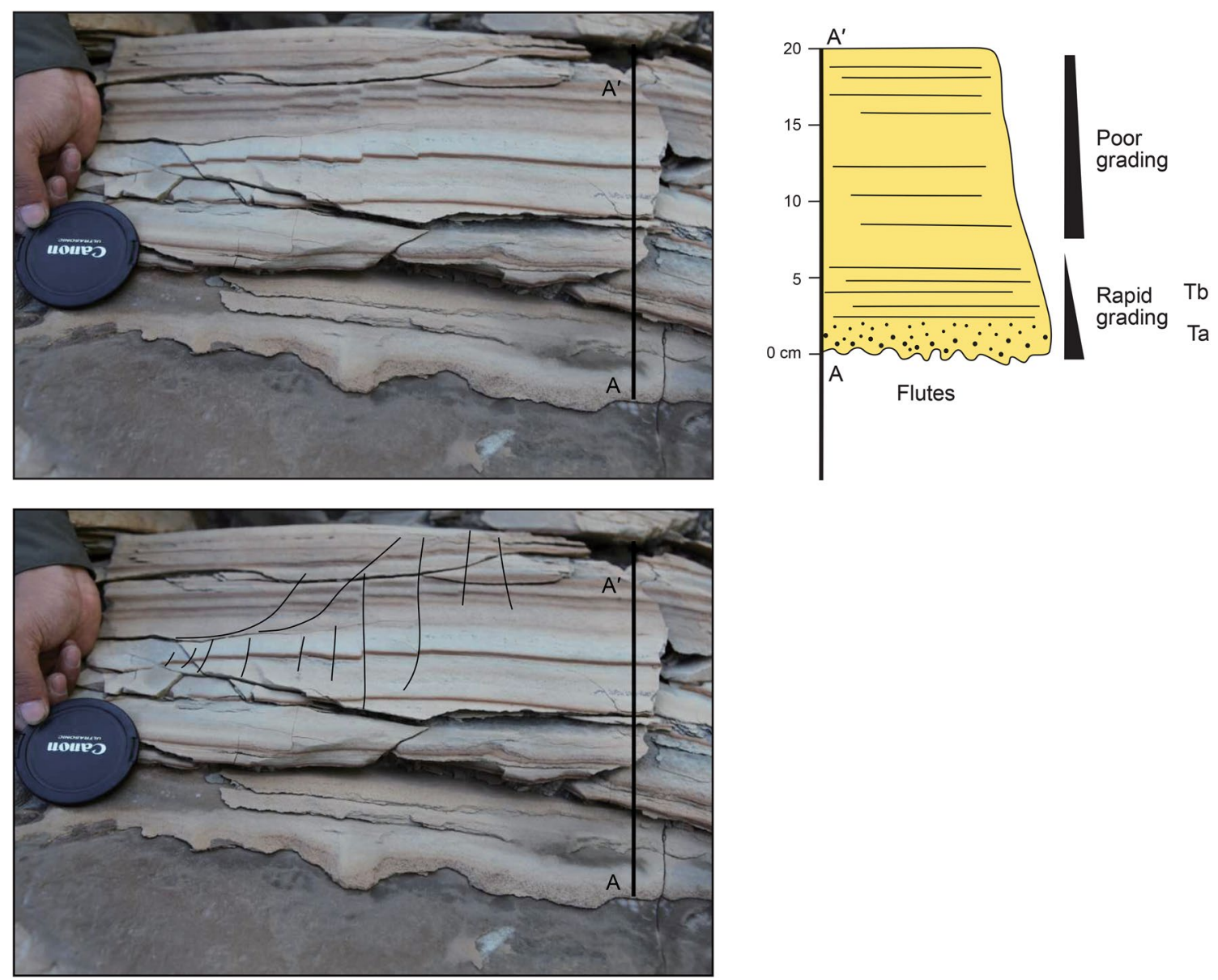

Fig. 5 High-density turbidite with synsedimentary faults. The faults are confined in one bed, which suggests they were formed during a single flow rather than due to external factors

\subsection{Hybrid event beds}

\subsubsection{Description}

The hybrid event beds of the Lucaogou Formation vary in thickness from 10 to $30 \mathrm{~cm}$, with grain sizes up to mediumgrained sand (Fig. 9a, b). The hybrid event beds occur less frequently than sandy turbidite beds, as described in Sect. 4.1, which are characterized by three divisions (Fig. 9a, b). The basal division is comprised of light yellow or yellowish-brown, medium-grained sandstone. This sandstone is essentially well-sorted and constitutes $\mathrm{Ca} 25-30 \%$ of the event bed. The second division consists of a homogenous matrix of dark grey siltstone with or without large rafted blocks (large blocks in Fig. 9a, and no large block in Fig. 9b). The third division is composed of planar laminated very fine-grained sandstone (Fig. 9a) that grades into a homogeneous dark grey siltstone. Occasionally, planar laminated sandstone in the third division is absent (Fig. 9b).

\subsubsection{Interpretation}

The full bed is interpreted to record the passage of the flow that was initially turbulent (i.e., leaving massive basal clean sandy divisions) and was followed by the onset of a flow in which turbulence was highly damped via en masse deposition (linked debrite) (Fig. 9a, b; Haughton et al. 2003, 2009; Southern et al. 2017; Fonnesu et al. 2018; Pierce et al. 2018; Shan et al. 2019a, b). The hybrid event bed type can reflect a more down-dip position where the debris flow component has almost outrun a forerunning turbidity current (see HEB5 and HEB6 in Pierce et al. 2018). Hybrid event beds, containing large rafted blocks in the $\mathrm{H} 3$ division (Fig. 9a), probably indicate short-distance transport and transformation of failure due to loading of the adjacent slope or partial transformation from a debris flow (Haughton et al. 2003). Hybrid event beds with separated mud clasts (Fig. 9b) probably represent down-dip equivalents of beds with large blocks or suggest erosional bulking of the turbidity current (Haughton et al. 2003; Fonnesu et al. 2015, 2018). 

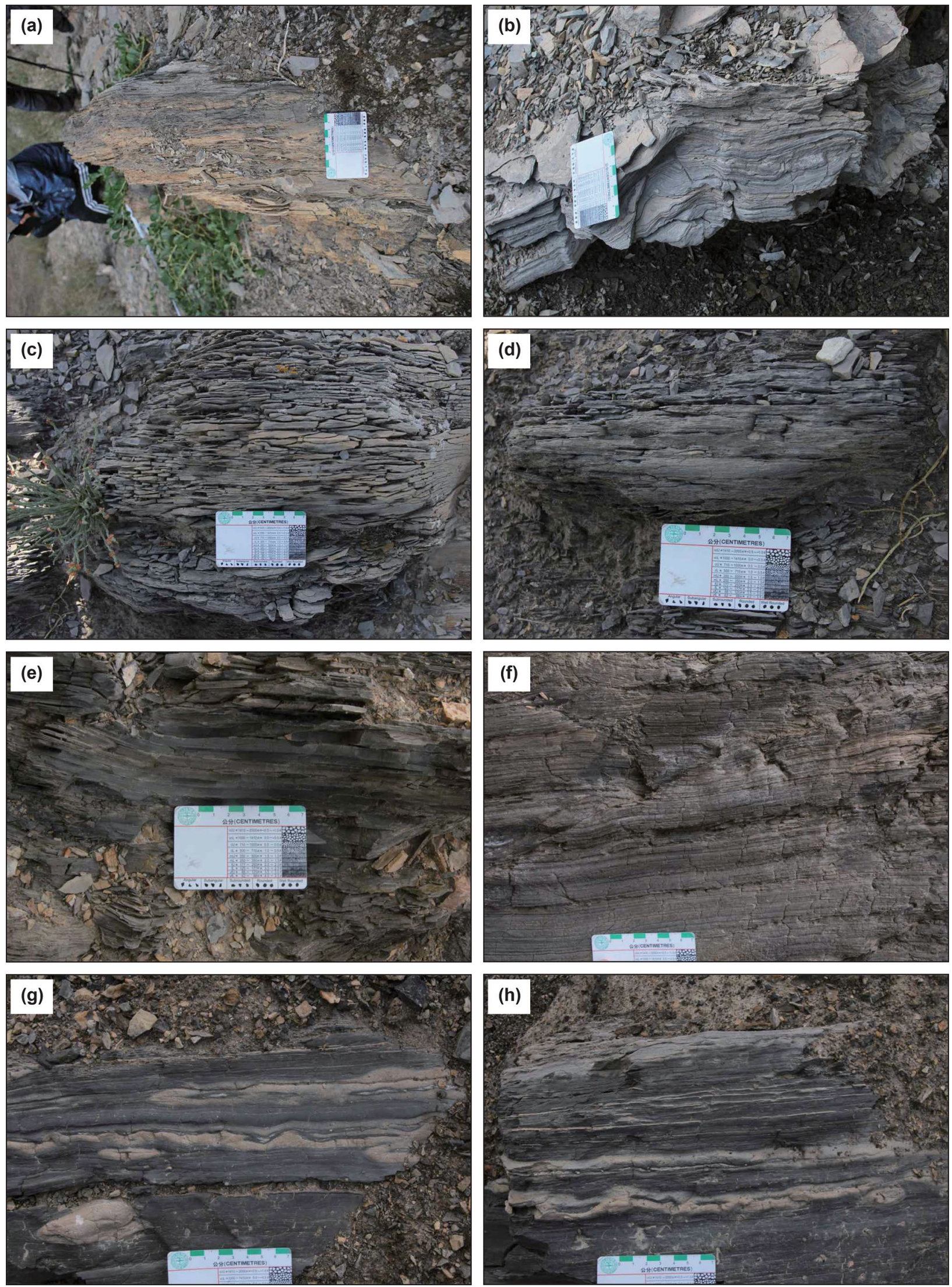
4Fig. 6 Low-density turbidite. a Very thin-bedded turbidite. b Small ripples can be observed in thin layer of siltstone. c Thin-bedded turbidite with ripple cross-laminated siltstone. $\mathbf{d}$ Ripple cross-laminated siltstone. e Thin-medium-bedded mudstone interbedded with ripple cross-laminated siltstone. f Thin-bedded dark grey mudstone interbedded with cross-laminated siltstone. $\mathbf{g}$ Thin-bedded black mudstone interbedded with thin-medium-bedded sandstone. h Thin-bedded black mudstone interbedded with cross-laminated siltstone

\subsection{Slump deposits}

\subsubsection{Description}

The slump, which represents the dimensions of the available outcrop, extends for approximately $20 \mathrm{~m}$ and comprises 10-m-thick folded depositional beds (Fig. 10). Strata above and below the slumped unit are parallel, which confirms that the deformed unit between the two parallel units is a slump (Figs. 10, 11a). The slump is separated from the overlying conformable strata via a concordant upper contact and detached from the underlying layers by a flat-lying basal decollement or detachment surface (Fig. 10).

\subsubsection{Interpretation}

Gregory (1969) proposed soft-sediment deformation for the discrete nature of the deformation unit encompassed by the undeformed units. The underlying strata were already consolidated, and no substrate was incorporated into the slump given that the basal decollement surface was not locally erosive and deposition underlying the decollement was not deformed.

\section{Depositional architecture in the Lucaogou Formation}

The Jiucaiyuanzi section and Dalongkou section have sand contents of $\sim 20 \%$ and $\sim 15 \%$, respectively. The successions of the Lucaogou Formation are dominated by thin-bedded turbidites $(\sim 70 \%)$ and subordinate thick-bedded amalgamated beds $(\sim 30 \%)$, which contain both turbidites and hybrid event beds.

\subsection{Amalgamated shallow channel fill and sheet}

Amalgamated shallow channel fill and sheets can be identified in the Lucaogou Formation, which comprise 20-40\% of the Lucaogou Formation's stratigraphy (Figs. 3 and $11 \mathrm{a}-\mathrm{c})$. The amalgamated sheets with no shallow channels were observed in the Dalongkou section. In contrast, several shallow channel fills in amalgamated beds can be identified in the Jiucaiyuanzi section (Fig. 11b, c). Amalgamated architectures are sand-dominated with a thickness of 5-40 m, which represents a lobe deposit that contains numerous lobe elements (Figs. 11a, b, 12a). Thus, the thickness of the lobe deposits ranges from 5 to $40 \mathrm{~m}$. Thick amalgamated shallow channel fill/sheet consists of approximately 20 bed sets (Fig. 11c), where the thickness of each bed set thickness ranges from 1 to $4 \mathrm{~m}$. A bed set is composed of 5-10 beds (Fig. 11c). Tabular-like thin- to medium-bedded (most bed thickness ranging from 0.1 to $0.5 \mathrm{~m}$ ) turbidite beds comprise the majority of the beds, with subordinate hybrid event beds. Several scours observed in the amalgamated architectures (Fig. 11c). Their dimensions can reach tens of meters in width and a few meters in depth (Fig. 11c). The infill of scour consists of thin-bedded siltstone and sandstone turbidite beds.

Previously reported amalgamated thick-bedded turbidites (bed thickness ranging from 1 to $3 \mathrm{~m}$ ) that fill sheet geometries potentially formed in proximal lobe settings (Lowe 1982; Piper and Normark 1983; Prélat et al. 2009). The bed thicknesses of these amalgamated beds typically range from 0.1 to $0.5 \mathrm{~m}$, much thinner than the bed thicknesses of proximal the lobe facies. In amalgamated beds, some tabular beds (sheets) are truncated by shallow channel bodies that are filled with thick-bedded turbidites with a bed thickness of 0.3-0.5 m (Fig. 11c). Amalgamated sheets/channels may represent a distributive lobe system, with sandy stacked sheet and shallow channel elements deposited mainly via sandy and muddy turbidity currents, as well as hybrid flows (Pierce et al. 2018). In the Jiucaiyuanzi section, several shallow channel fills in the amalgamated beds, as shown in Fig. 11c, may represent progradation of the lobe system, which is likely a result of a lake-level drop or an increase in sediment supply (Bernhardt et al. 2017). The shallow channels in the fan fringe setting indicate sediment bypass further down dip toward the most distal area (Mueller et al. 2017). The infill of scour has been interpreted as reworked finegrained tails of bypassing flows (Hofstra et al. 2015). The scour tends to occur in zones of flow expansion, such as lobe distributary channel termini (Macdonald et al. 2011). The composite erosion surfaces (scours) in Fig. 11c potentially indicate sediment bypass down system (Stevenson et al. 2015). The change in flow confinement and a local increase in the gradient are possible reasons for the development of the bypass surfaces or scours (Van der Merwe et al. 2014).

\subsection{Isolated sheet}

Isolated beds constitute the majority of the Lucaogou Formation. Isolated sand sheets are thin fine-grained sandy turbidites characterized by a sheet-like geometry without scour-and-fill, shallow isolated scours, or other large-scale erosional surfaces (Fig. 12b-e). Individual fine-grained sandstone or coarse siltstone is laterally continuous, which 

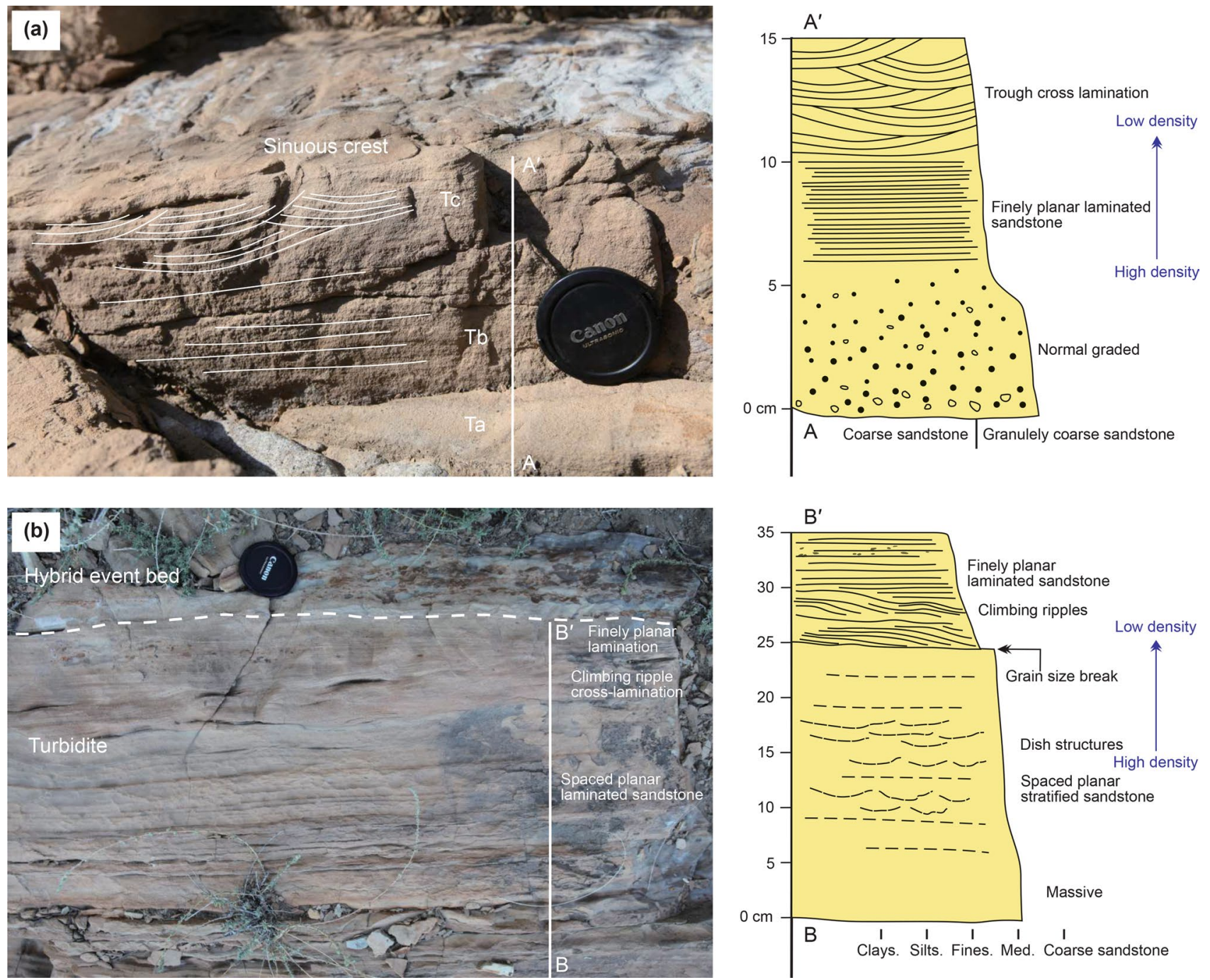

Fig. 7 Other types of turbidite. a Normal graded and massive sandstone $\rightarrow$ fine-scale planar laminated sandstone $\rightarrow$ cross-laminated sandstone. $\mathbf{b}$ Massive sandstone $\rightarrow$ spaced planar laminated sandstone $\rightarrow$ climbing-ripple cross-laminated sandstone $\rightarrow$ fine-scale planar laminated sandstone. A grain size break can be observed above spaced laminated sandstone

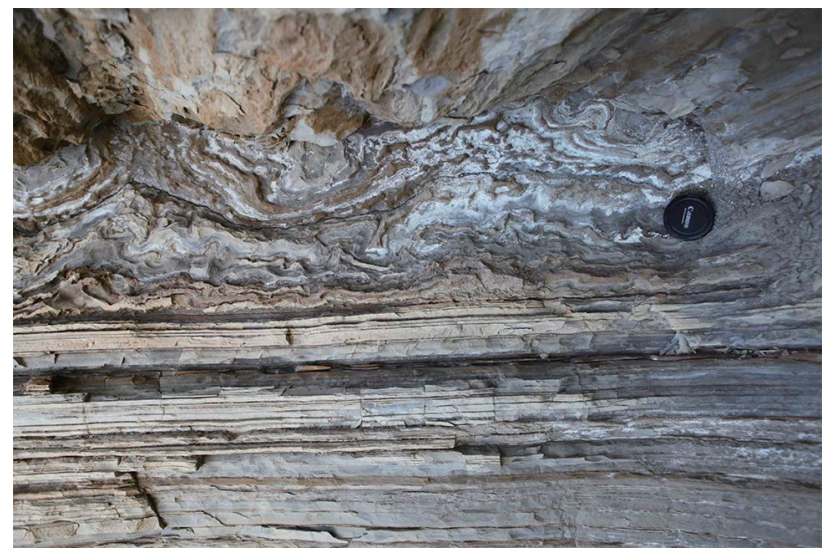

Fig. 8 Train of asymmetric folds was commonly found on top of finescale planar bedded beds and beneath another turbidite bed is based by a flat boundary (Fig. 12b-e). Sheet thickness is a few tens of $\mathrm{cm}$. Turbidites compose an isolated sheet (Fig. 12b-e).

Thinner-bedded turbidites that fill unconfined sheets have been interpreted as interlobe deposits, which were accumulated in fan fringe or lobe-fringe settings (Pickering 1981b; Carlson and Grotzinger 2001; Baylis and Pickering 2015). Fan fringe-specific characteristics, such as a flat base, sheet geometry, lateral continuity, and high proportion of mudstone and fine-grained turbidites, represent deposits in a lowenergy setting (So et al. 2013). Thick, laminated mudstone, left by vertical settling from the lake water column, is considered as background sedimentation within a basin plain.

Decelerating turbidity currents that become unconfined due to a loss of in the flow competence and capacity can form sheet-like sandy deposits (Lowe 1982). Interlobes are 

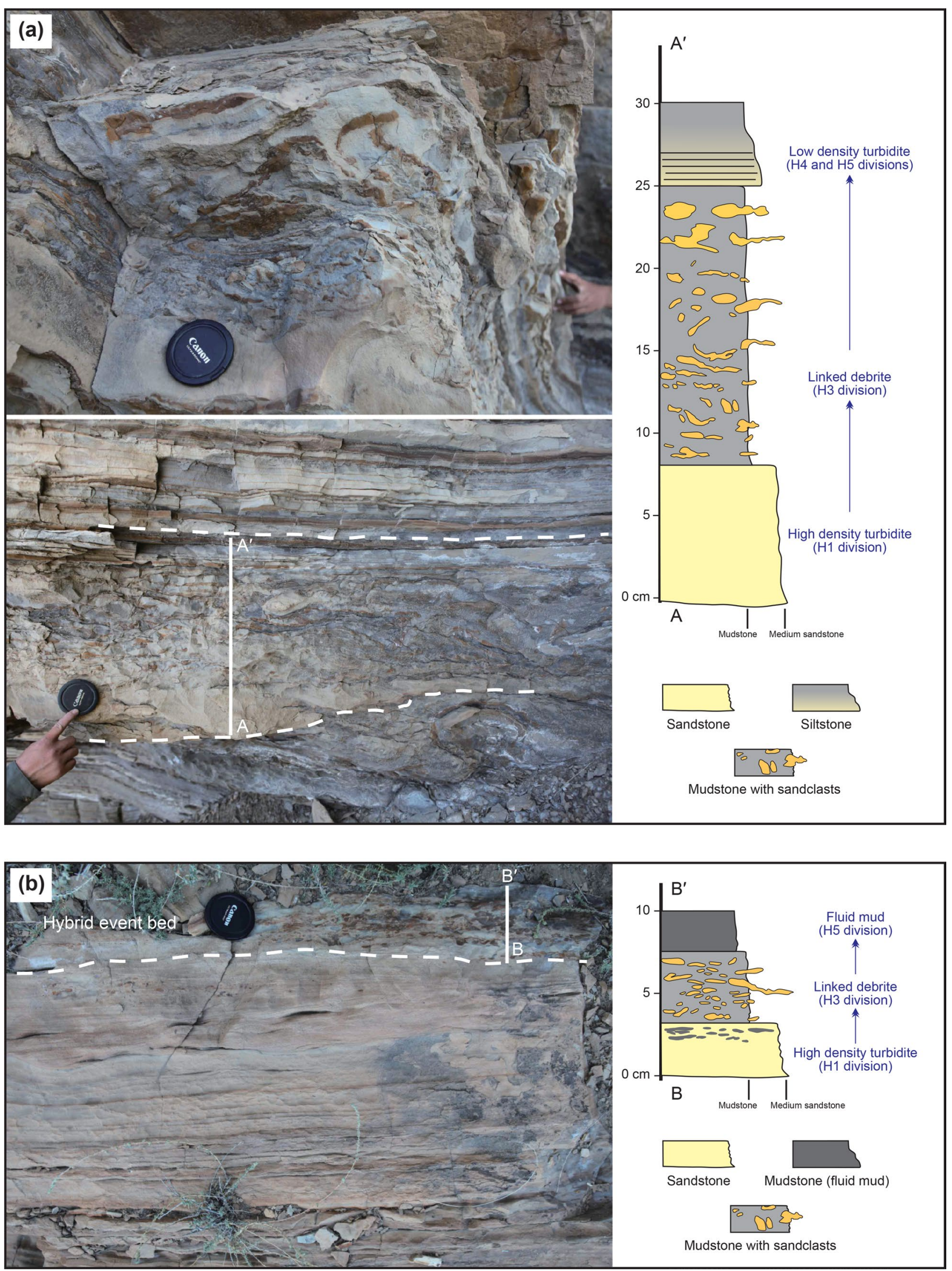

Fig. 9 Hybrid event beds of Lucaogou Formation. The bed thickness is thin to medium with a thickness of $10-40 \mathrm{~cm}$. It has three internal divisions including basal high-density turbidite (H1), linked debrite (H3), and mud cap (H5) 
characterized by an isolated sheet-like geometry and filled with turbidites and hybrid event beds (Pickering 1981a, b; Prélat et al. 2009; Pierce et al. 2018). Scour features or isolated scours in isolated sheets do not indicate that the isolated sheet succession accumulated in a depositional zone as opposed (Van der Merwe et al. 2014; Stevenson et al. 2015).

\section{Discussion}

\subsection{Bed types and flow mechanisms of fan fringe facies in the Lucaogou Formation}

Previous researches on the Lucaogou Formation have focused on reservoir geology (Kuang et al. 2012; Gao et al. 2016; Wu et al. 2016; Zhao et al. 2017; Cao et al. 2016, 2017; Luo et al. 2018; Su et al. 2018). Thus, the bed type and architecture study here represents an unreported aspect.

Three bed types were identified in this study, including turbidite, hybrid event bed, and slump (Fig. 13). The dominant turbidites and subordinate hybrid event beds, as well as similar thin bedded architecture elements of the Lucaogou Formation, indicate that the deposits represent fan fringe facies (Fig. 13). Our study shows that the deep lake succession in the Lucaogou Formation contains stacked deposits emplaced by a number of flow types, including high-density turbidity currents, low-density turbidity currents, and hybrid flows. No terrestrial plant debris or tree trunks were observed in the turbidites or hybrid event beds, which precludes a hyperpycnite origin (Zavala and Arcuri 2016). The distal turbidites and hybrid event beds described here probably evolved from proximal slumps triggered by
Fig. 11 Depositional architecture in the Lucaogou Formation. The Lucaogou Formation is dominated by amalgamated sheet/channel and isolated sheets. a Lucaogou Formation Dalongkou section is composed of amalgamated sheet/channel and isolated sheets as well as some slump deposits. b Lucaogou Formation in Jiucaiyuanzi section also comprises amalgamated sheet/channel and isolated sheets. $\mathbf{c}$ Amalgamated beds in Jiucaiyuanzi section

unstable topography, storms, or earthquakes rather than a hyperpycnal flow. Most turbidite beds and hybrid event beds of the Lucaogou Formation vary in thickness from a few centimeters to less than $50 \mathrm{~cm}$ (see 4 bed types of deep water system in the Lucaogou Formation). The thin bed thickness here is different from numerous thick turbidites and hybrid event beds, with a thickness of $>1 \mathrm{~m}$ in the fan fringe (Talling et al. 2004; Pierce et al. 2018), which likely indicates the most distal deposit of the sub-lacustrine fan (Kane and Pontén 2012).

Due to absence of wave ripples and storm-related structures (i.e., hummocky and swaley cross-bedding), the deposits here are interpreted as deposited in a setting below the storm wave base, consistent with findings of Carroll et al. (1998). Peters and Loss (2012) reported that the storm wave base could be as deep as $200 \mathrm{~m}$. As a result, we suggest that the deposits here were considered as being deposited in a deep lake setting, probably with a water depth of $>200 \mathrm{~m}$.

\subsubsection{Turbidites and their flow mechanism in the Lucaogou Formation}

Abundant mud clasts are present in massive and mediumcoarse grained sandstone beds (Fig. 4c-e). The clasts reveal

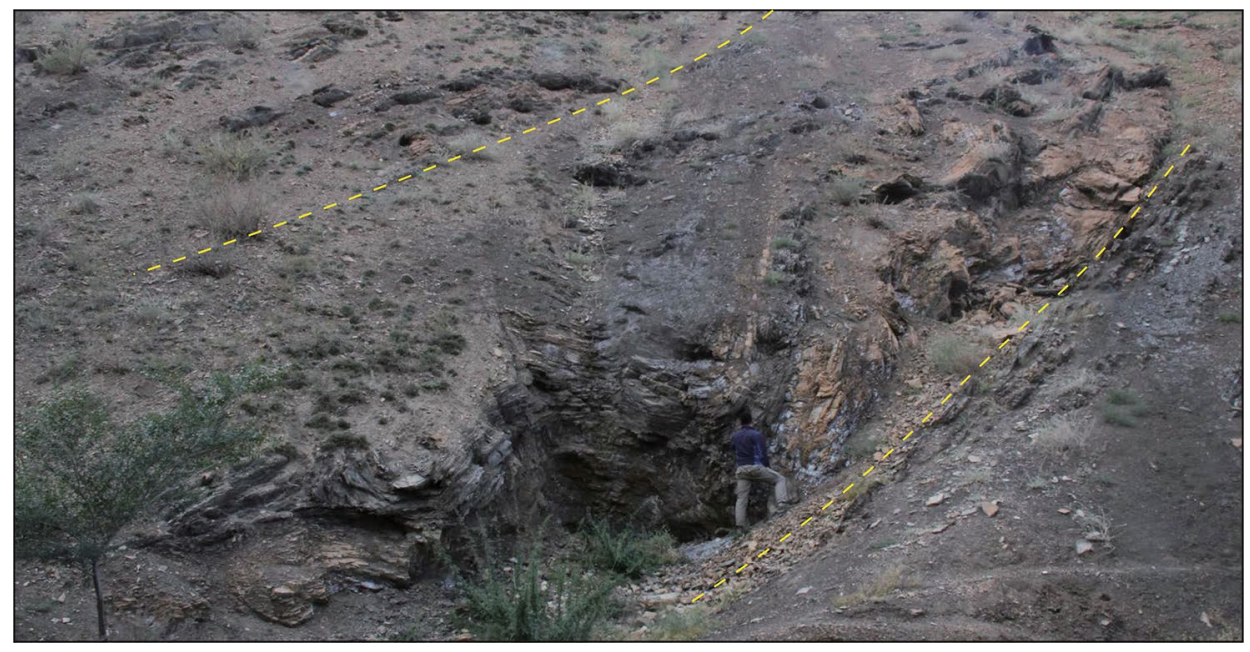

Fig. 10 Slump deposits in the Lucaogou Formation. The slump is separated from overlying, conformable strata by a concordant upper contact, and detached from underlying strata by a flat-lying basal decollement or detachment surface. The flat-lying detachment surface does not show erosional feature, and the underlying strata is not deformed 

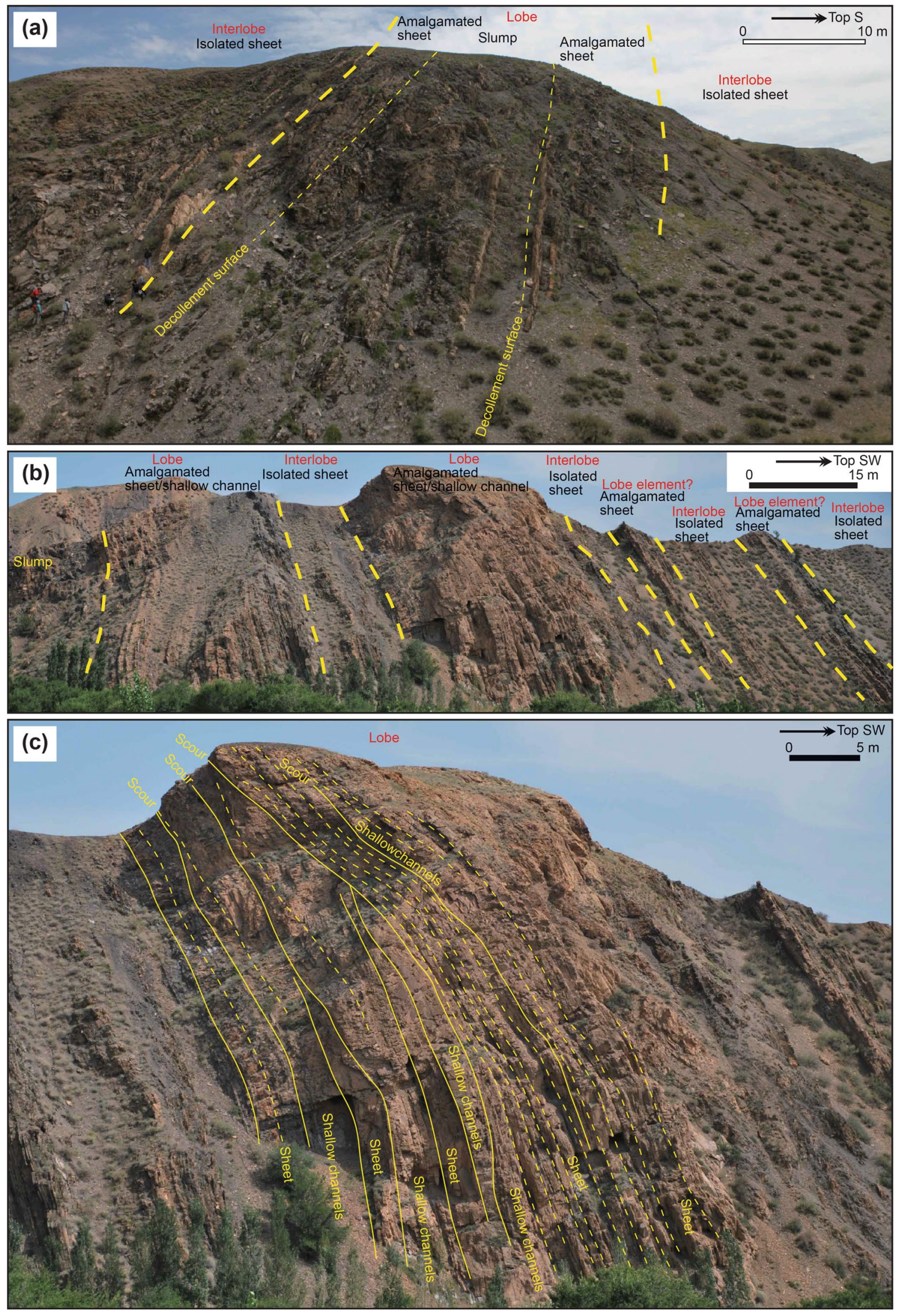
both a high erosional capability and frequent interactions between high-density turbidity currents and the muddy lake floor. Current studies suggest that dense flows tend to erode substrates when reaching areas of unconfinement (Pohl et al. 2019). The fan fringe setting corresponds to the type of a setting where the lobe distributary channels begin to disappear and turbidity currents erode the substrate. The isolated sheet and shallow sub-lacustrine channels here, with a width/depth ratio of $>10$, confirm the widening and disappearance of the channels. Turbidity currents can experience significant changes due to the incorporation of mud clasts in fan fringe settings because the partial disaggregation of mud clasts can potentially be a key to the suppression of turbulence and modifications to the flow behavior (Haughton et al. 2009). Mud clasts, however, were not observed in the low-density turbidite in Lucaogou Formation, which is likely because that low-density turbidity currents cannot erode substrates due to their low concentrations.

The appreciable current ripple cross-laminated sandstone observed in the fan fringe facies (low-density turbidite) records flow dilution (Fig. 13), which represents the downdip equivalent of an up-dip high-concentrated flows due to a decrease in the flow concentration with a flow runout. The distal diluted trailing current tails can partition or runout from the high-density turbidity current or hybrid sediment gravity flows (Davis et al. 2009). More specifically, current ripple laminated sandstones are typically observed in offaxis and fringe settings (Hodgson 2009).

\subsubsection{Hybrid event beds and their flow mechanism in the Lucaogou Formation}

Hybrid event beds are an important component of deep water fan fringe facies (Talling et al. 2004; Haughton et al. 2009; Kane and Pontén 2012). Several origins have been proposed to explain hybrid event beds, including (1) the partial transformation from a debris flow and the generation of a forerunner turbidity current (Haughton et al. 2003; Talling et al. 2004); (2) sea-floor erosion and flow bulking (Talling et al. 2004); (3) the loading of an adjacent slope and the generation of a slump or debris flow (Pierce et al. 2018); and (4) the deceleration of a transitional flow (Marr et al. 2001; Kane and Pontén 2012).

The bed thickness of hybrid event beds in the Lucaogou Formation is less than $50 \mathrm{~cm}$. The hybrid event beds in the Lucaogou Formation are characterized by nearly subequal proportions of a massive lower sandstone and argillaceous upper divisions or greater proportions of chaotic muddy divisions (Fig. 9). Three- or four-division beds are typical. The majority of the hybrid event beds (ca 70\%) contain the H3 division, with chaotic distributed $\mathrm{cm}$-scale mud clasts and without large blocks inside (Fig. 9b), while other hybrid event beds (ca 30\%) are characterized by large blocks that characterize the H3 division (Fig. 9a). The hybrid event beds with large blocks are associated with amalgamated beds, whereas hybrid event beds without large rafted blocks dominate the isolated sheet architecture.

The thin-bedded character of the hybrid event beds confirms a fan margin setting (Pierce et al. 2018). Energetic flows, capable of locally overloading and eroding the lake floor, generated the large blocks, carrying them relatively short distances before arresting (Fonnesu et al. 2018). The hybrid event beds, with floating mud clasts and absent of large blocks (Fig. 9b), were likely deposited by less energetic flows and represent down-dip equivalent expressions of hybrid event beds with large blocks. Erosional bulking is proposed here to interpret hybrid event beds with large blocks (Fonnesu et al. 2015, 2018). Rapid deceleration of the hybrid flow and longitudinal transformation, due to lateral hydrodynamic fractionation of clay and flaky particles, were potentially responsible for the formation of hybrid event beds without rafted blocks here (Haughton et al. 2003; Baas et al. 2011; Pyles et al. 2013). In fan fringe settings, a greater or sub-equal proportion of the debrite division indicates that the sandy lower bed division (H1) begins to thin and the linked debris flow component (H3) outran the forerunner sandy turbidity current. Thus, hybrid event beds imply a further down-dip position of the lobe and lobe fringe of the main sandy fairway (Pierce et al. 2018).

Far-travelled hybrid flows tend to exhibit significant proportions of transitional flow deposits (H2 division) such as the Britannia Sandstone and Wilcox formations (Lowe and Guy 2000; Kane and Pontén 2012). Contrary to an abundant $\mathrm{H} 2$ division that exhibits a long runout, the absence of banded beds (H2 division) in the Lucaogou Formation probably indicate that distal partitioning of the flow into cohesive and turbulent component occurred over a small length scale (Haughton et al. 2009; Fonnesu et al. 2015). Flows that partition over short length scales in smaller submarine fans, i.e., size of less than $20 \mathrm{~km}$, inhibit the occurrence of transitional flow deposits (banded beds) (Haughton et al. 2009; Kane and Pontén 2012). Thus the lack of H2 division here likely indicates a short length scale in the small sub-lacustrine fan.

In the hybrid event beds, the debrite division (H3 division) contains mudstone and sandstone fragments (up to the decimeter scale) surrounded by a matrix. Thus, this division is extremely heterogeneous.

\subsubsection{Slump and its flow mechanism in the Lucaogou Formation}

The example in this study also underlines the importance of syndepositional processes in the fan fringe settings including slumps and brittle deformation (Figs. 5, 10). Slump and 

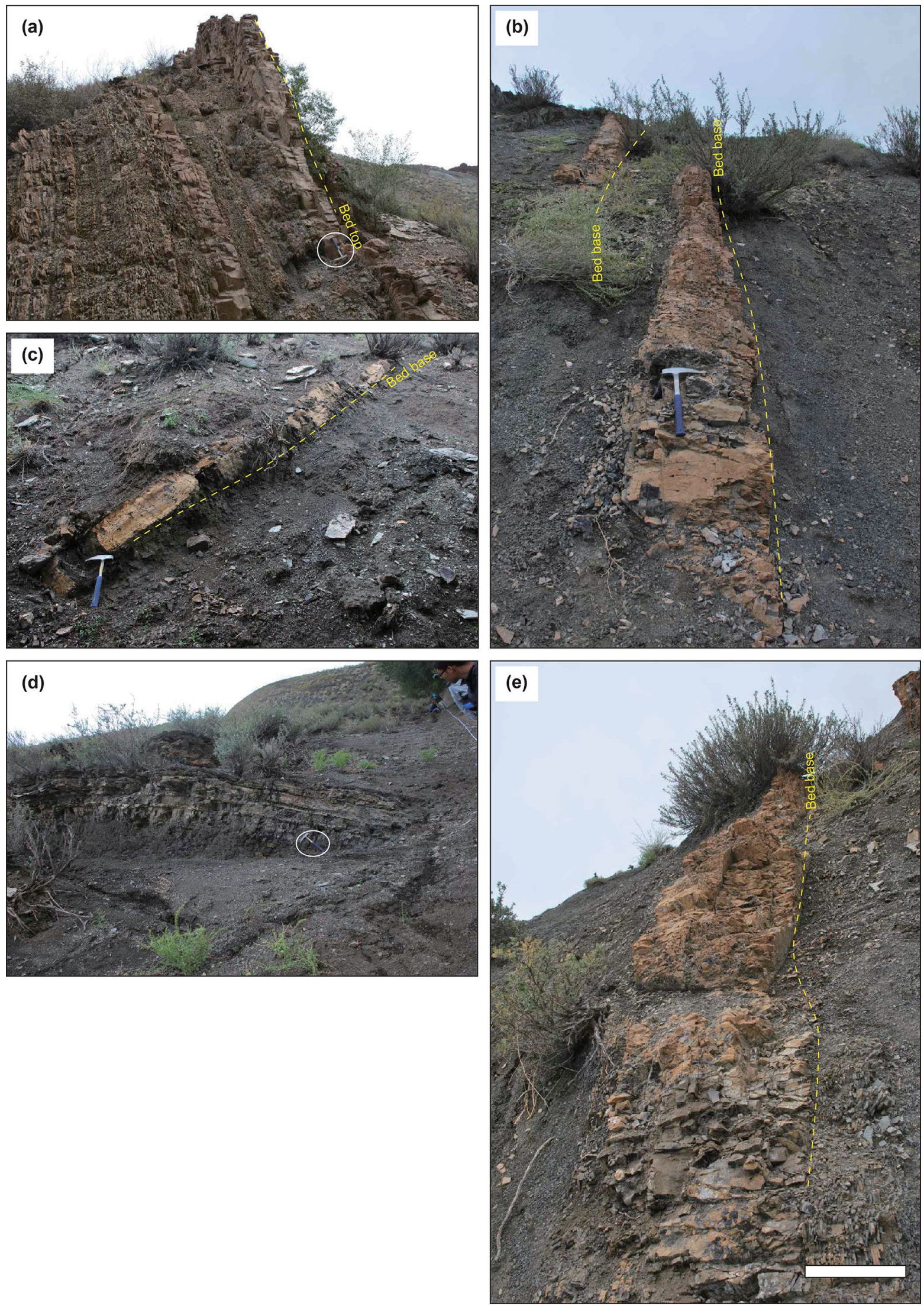

Fig. 12 Depositional architecture in the Lucaogou Formation. a Amalgamated sheets. b-e Isolated sheets. The bed thickness ranges from a few $\mathrm{cms}$ to $40 \mathrm{~cm}$. Most isolated sheets were filled with turbidites 


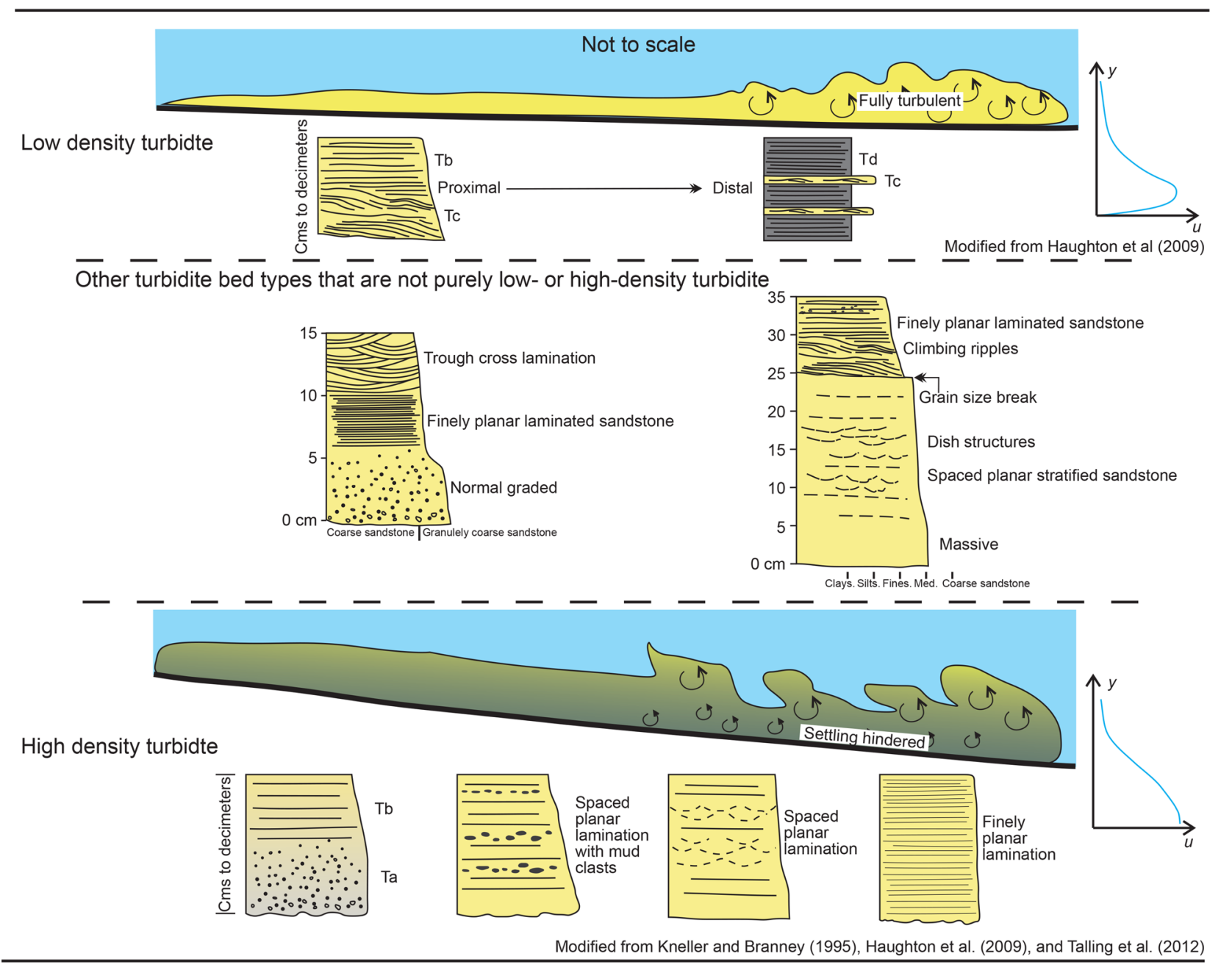

Hybrid event beds
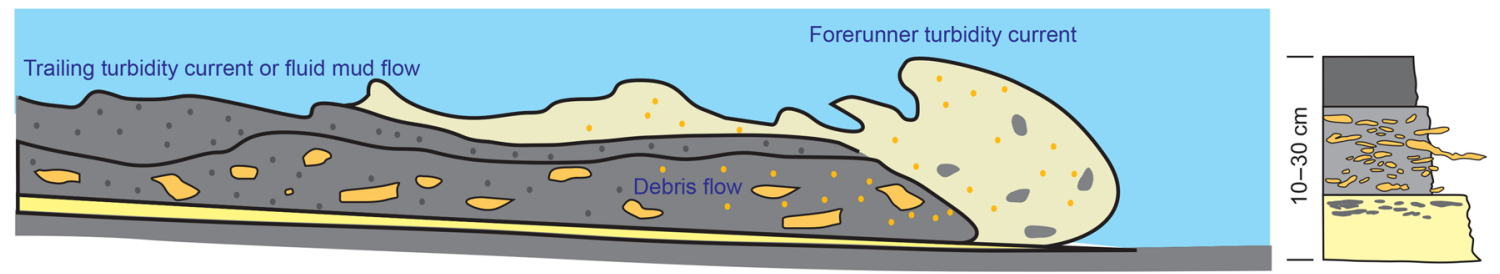

Modified from Haughton et al. (2009)
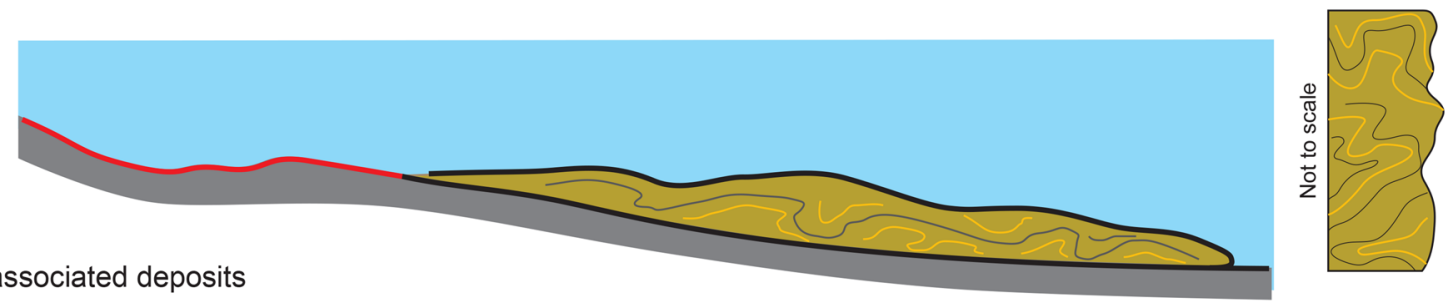

\section{Slump and associated deposits}

Fig. 13 The bed types and flow mechanism for the fan fringe deposits in the Lucaogou Formation (modified after Kneller and Branney (1995), Haughton et al. (2009), and Talling et al. (2012)) 
Proximal lobe facies

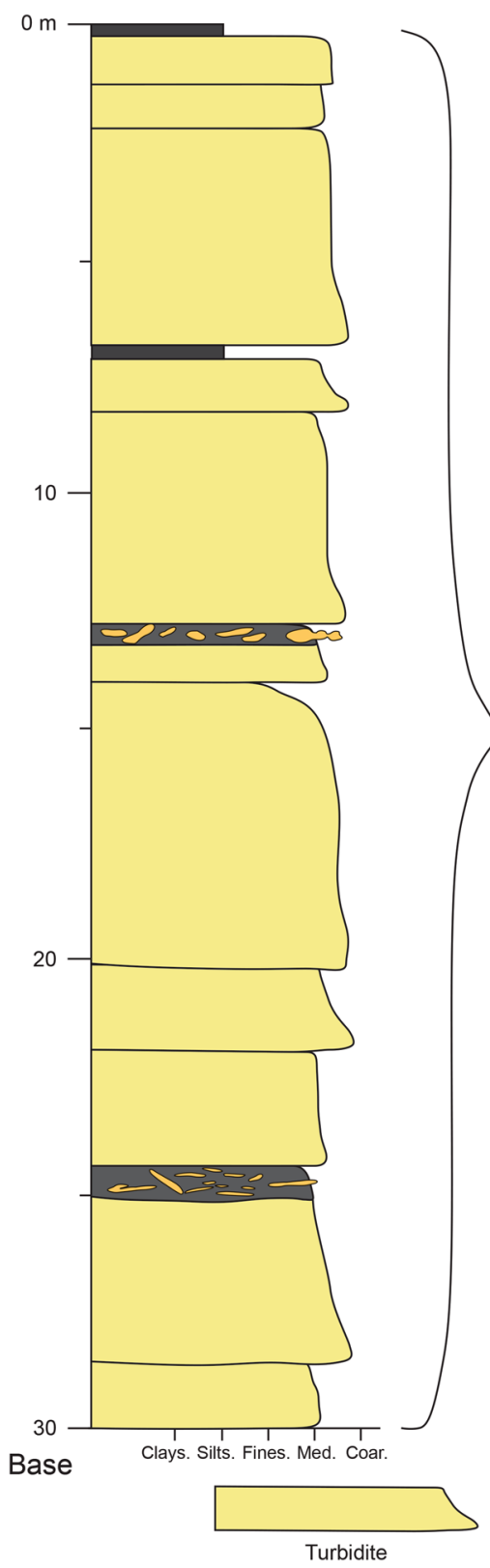

Lobe deposit (homolithic facies)
Distal lobe facies
(heterogeneties)

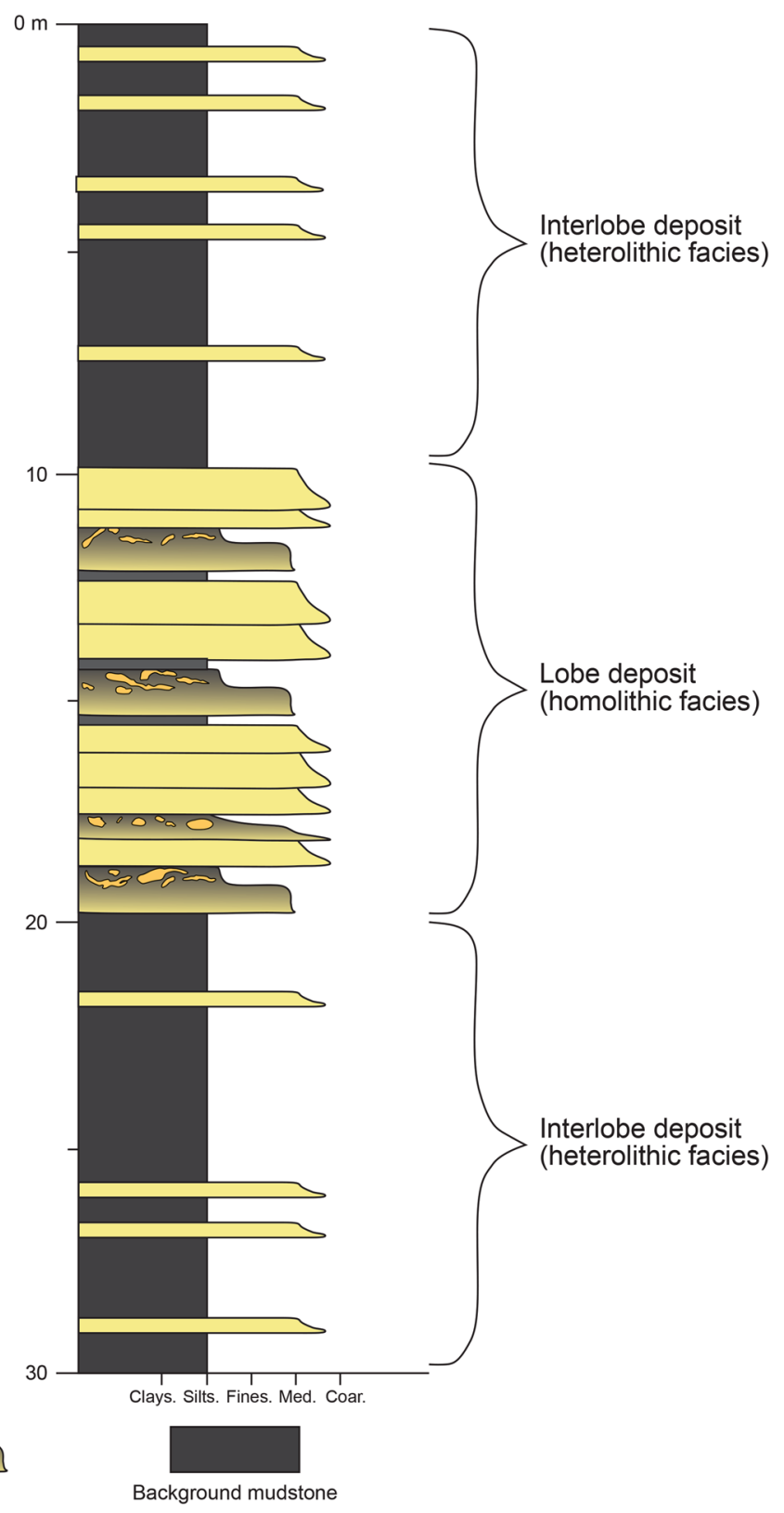

Fig. 14 Two sedimentary logs summarizing the sedimentary characteristics that describe the proximal lobe and fan fringe. The sequence of proximal lobe deposit summarized is slightly; modified from Haughton et al. (2003) and Prélat et al. (2009). The sequence of fan fringe deposit is summarized based on observation of Lucaogou Formation and in the literature (Prélat et al. 2009; Spychala et al. 2017a, b)

brittle deformation were potentially generated by high shear stress, which was exerted by the turbidity currents or hybrid flows. Deformation within the Lucaogou Formation suggests that the lake floor on which it was deposited was unstable.

\subsection{Implication for heterogeneity in the fan fringe facies}

Thin-bedded isolated beds represent the majority of the event beds encountered in the Lucaogou Formation (Fig. 3). Thin-bedded sand beds represent an interlobe deposit in the 
fan fringe facies (Fig. 14). The interlobe deposit (thin-bedded beds) in the Lucaogou Formation accounts for ca $70 \%$ of the fan fringe facies, which shows that the fan fringe deposit is dominated by heterolithic facies. In comparison with the lobe axis and lobe off-axis, the thin sandstone bed thickness and the low sandstone amalgamation of the isolated beds here in the Lucaogou Formation (fan fringe facies) result in a worse reservoir quality. Thus, the fan fringe facies herein, as well as based on the existing literature (Haughton et al. 2003; Spychala et al. 2017a, b), may not be an appropriate target for energy exploration and exploitation.

The fan fringe deposits described herein contain both homolithic facies (sandprone thick-bedded sand beds) and heterolithic facies (thin-bedded sand beds interbedded with silt beds) (Fig. 14). Although sandprone thick-bedded beds contain $30 \%$ to $40 \%$ hybrid event beds in our study and hybrid beds probably decrease the reservoir quality (Spychala et al. 2017a, b), the thick-bedded beds here were considered as homolithic facies, because homolithic facies is defined based on bed amalgamation and bed thickness (>30 cm thick) (Etienne et al. 2012). Thick-bedded beds represent amalgamated fan fringe elements (Fig. 14). If thick-bedded and amalgamated beds comprise more than $50 \%$ of the hybrid event beds, it is best to evaluate the reservoir porosity and permeability before classifying it as homolithic facies, because the hybrid bed probably significantly decreases the reservoir quality. The flow type controls the lobe bed formation and lobe element-scale heterogeneities (Amy et al. 2009). Larger-scale heterogeneities (lobe scale) depend on both flow types and external factors, including sea-level change, sediment supply, and climate change (Etienne et al. 2012; Spychala et al. 2017a).

\section{Conclusion}

Key findings on the character of the bed types in the Lucaogou Formation are as follows (summarized in Figs. 13, 14):

The Lucaogou Formation outcrop consists of lowdensity turbidites, high-density turbidites, other turbidite types, hybrid event beds, and slump deposits. High- and low-density turbidites constitute the major bed types of the Lucaogou Formation.

The hybrid event beds in the Lucaogou Formation reflect the flow transformation through flow deceleration and flow bulking, as well as increasing flow viscosity and interaction between the depositing flow and muddy lake floor.

Isolated sheets comprise the majority of the Lucaogou Formation. Thin- to medium-bed thicknesses (mostly ranging from 0.1 to $0.5 \mathrm{~m}$ ) and sheet geometries suggest that the Lucaogou Formation represents fan fringe deposits.
These were formed mainly via turbidity currents and supplemented by hybrid flows and slumps.

In amalgamated beds, erosion also occurs in fan fringe settings due to the abundant mud clasts and scours in the amalgamated architectures, which is likely due to the progradation of the lobe system.

The fan fringe deposit in the Lucaogou Formation comprises amalgamated, thick-bedded homolithic facies and thin-bedded heterolithic facies. Heterolithic facies constitutes the majority of the successions, which indicates that the fan fringe deposit forms these heterogeneities.

Acknowledgements The comments and suggestions performed by two anonymous reviewers and the editor Dr. Chenglin Gong deeply improve this manuscript. We also thank Dr. Spychala, who offers many useful comments on our last version of the manuscript. The study was funded by National Science and Technology Major Project (Grant No. 2017ZX05001-002) and National Natural Science Foundation of China (Grant No. 41802129).

Open Access This article is licensed under a Creative Commons Attribution 4.0 International License, which permits use, sharing, adaptation, distribution and reproduction in any medium or format, as long as you give appropriate credit to the original author(s) and the source, provide a link to the Creative Commons licence, and indicate if changes were made. The images or other third party material in this article are included in the article's Creative Commons licence, unless indicated otherwise in a credit line to the material. If material is not included in the article's Creative Commons licence and your intended use is not permitted by statutory regulation or exceeds the permitted use, you will need to obtain permission directly from the copyright holder. To view a copy of this licence, visit http://creativecommons.org/licenses/by/4.0/.

\section{References}

Allen JRL. Asymmetrical ripple marks and the origin of water-laid cosets of cross-strata. Geol J. 1963;3(2):187-236. https://doi. org/10.1002/gj.3350030201.

Allen JRL. Current Ripples. Amsterdam: North-Holland Publishing Co.; 1968. p. 433.

Allen JRL. The Bouma division A and the possible duration of turbidity currents. J Sediment Res. 1991;61(2):291-5. https://doi. org/10.1306/D42676F4-2B26-11D7-8648000102C1865D.

Amy LA, Mccaffrey WD, Talling PJ. Special issue introduction: sediment gravity flows-recent insights into their dynamic and stratified/composite nature. Mar Pet Geol. 2009;26(10):1897-9. https://doi.org/10.1016/J.MARPETGEO.2009.02.016.

Baas JH, Best JL, Peakall J. Depositional processes, bedform development and hybrid bed formation in rapidly decelerated cohesive (mud-sand) sediment flows. Sedimentology. 2011;58(7):195387. https://doi.org/10.1111/J.1365-3091.2011.01247.X.

Bayliss NJ, Pickering KT. Transition from deep-marine lower-slope erosional channels to proximal basin floor stacked channellevée-overbank deposits, and synsedimentary growth structures, Middle Eocene Banastón System, Ainsa basin. Spanish Pyrenees Earth-Sci Rev. 2015;144:23-46. https://doi.org/10.1016/J. EARSCIREV.2014.11.015.

Bernhardt A, Schwanghart W, Hebbeln D, et al. Immediate propagation of deglacial environmental change to deep-marine turbidite systems along the Chile convergent margin. Earth 
Planet Sci Lett. 2017;473:190-204. https://doi.org/10.1016/J. EPSL.2017.05.017.

Brooks HL, Hodgson DM, Brunt RL, et al. Deepwater channel-lobe transition zone dynamics: processes and depositional architecture, an example from the karoo basin, south africa. Geol Soc Am Bull. 2018;130(9-10):1723-46. https://doi.org/10.1130/B31714.1.

Butler RW, Eggenhuisen JT, Haughton P, et al. Interpreting syndepositional sediment remobilization and deformation beneath submarine gravity flows; a kinematic boundary layer approach. J Geol Soc. 2015;173(1):46-58. https://doi.org/10.1144/JGS2014-150.

Cao Z, Liu G, Kong Y, et al. Lacustrine tight oil accumulation characteristics: permian Lucaogou Formation in jimusaer sag, Junggar Basin. Int J Coal Geol. 2016;153:37-51. https://doi.org/10.1016/J. COAL.2015.11.004

Cao Z, Liu G, Xiang B, et al. Geochemical characteristics of crude oil from a tight oil reservoir in the Lucaogou Formation, Jimusar Sag. Junggar Basin AAPG Bull. 2017;101(1):39-72. https://doi. org/10.1306/05241614182.

Carlson J, Grotzinger JP. Submarine fan environment inferred from turbidite thickness distributions. Sedimentology. 2001;48(6):133151. https://doi.org/10.1046/J.1365-3091.2001.00426.X.

Carroll AR. Upper Permian lacustrine organic facies evolution, Southern Junggar Basin. NW China Organ Geochem. 1998;28(11):64967. https://doi.org/10.1016/S0146-6380(98)00040-0.

Carroll AR, Bohacs KM. Lake-Type Controls on Petroleum Source Rock Potential in nonmarine Basins. AAPG Bull. 2001;85(6):1033-53. https://doi.org/10.1306/8626CA5F-173B11D7-8645000102C1865D.

Carroll AR, Yunhai L, Graham SA, et al. Junggar basin, northwest China: trapped Late Paleozoic ocean. Tectonophysics. 1990;181:1-14. https://doi.org/10.1016/0040-1951(90)90004-R.

Carroll AR, Brassell SC, Graham SA. Upper Permian lacustrine oil shales, southern Junggar Basin, northwest China. AAPG Bull. 1992;76:1874-902. https://doi.org/10.1306/BDFF8B0A-171811D7-8645000102C1865D.

Carroll A, Graham S, Hendrix M, et al. Late Paleozoic tectonic amalgamation of northwestern China: sedimentary record of the northern Tarim, northwestern Turpan, and southern Junggar basins. Geol Soc Am Bull. 1995;107(5):571-94. https://doi.org/10.1130/00167606(1995)107\%3c0571:LPTAON\%3e2.3.CO;2.

Charvet J, Shu LS, Laurent-Charvet S. Paleozoic structural and geodynamic evolution of eastern Tianshan (NW China): welding of the Tarim and Junggar plates. Episodes J Int Geosci. 2007;30(3):162-86.

Cocks LRM, Torsvik TH. The dynamic evolution of the Palaeozoic geography of eastern Asia. Earth Sci Rev. 2013;117:40-79. https ://doi.org/10.1016/J.EARSCIREV.2012.12.001.

Davis C, Haughton P, McCaffrey, et al. Character and distribution of hybrid sediment gravity flow deposits from the outer Forties Fan, Palaeocene Central North Sea. UKCS Mar Pet Geol. 2009;26(10):1919-39. https://doi.org/10.1016/J.MARPE TGEO.2009.02.015.

Etienne S, Mulder T, Bez M, et al. Multiple scale characterization of sand-rich fan fringe deposit variability: examples from the Annot Sandstones Formation, Eocene-Oligocene. SE France Sediment Geol. 2012;273:1-18. https://doi.org/10.1016/J.SEDGE O.2012.05.003.

Fildani A, Normark WR. Late Quaternary evolution of channel and lobe complexes of Monterey Fan. Marine Geol. 2004;206(14):199-223. https://doi.org/10.1016/J.MARGEO.2004.03.001.

Fonnesu M, Haughton P, Felletti F, et al. Short length-scale variability of hybrid event beds and its applied significance. Mar Pet Geol. 2015;67:583-603. https://doi.org/10.1016/J.MARPE TGEO.2015.03.028.

Fonnesu M, Felletti F, Haughton PD, et al. Hybrid event bed character and distribution linked to turbidite system sub-environments: The
North Apennine Gottero Sandstone (North-west Italy). Sedimentology. 2018;65(1):151-90. https://doi.org/10.1111/SED.12376.

Fossen H. Structural geology. Cambridge: Cambridge University Press; 2016.

Gao G, Zhang W, Xiang B, et al. Geochemistry characteristics and hydrocarbon-generating potential of lacustrine source rock in Lucaogou Formation of the Jimusaer Sag, Junggar Basin. J Pet Sci Eng. 2016;145:168-82. https://doi.org/10.1016/J.PETRO L.2016.03.023.

Gladstone C, Sparks RSJ. The significance of grain-size breaks in turbidites and pyroclastic density current deposits. J. Sed. Res. 2002;72:182-91.

Gregory MR. Sedimentary features and penecontemporaneous slumping in the Waitemata Group, Whangaparaoa Peninsula, North Auckland, New Zealand. NZ J Geol Geophys. 1969;12:248-82. https://doi.org/10.1080/00288306.1969.10420236.

Haughton PDW, Barker SP, McCaffrey WD. 'Linked' debrites in sandrich turbidite systems - origin and significance. Sedimentology. 2003;50:459-82. https://doi.org/10.1046/J.1365-3091.2003.00560 .X.

Haughton PDW, Davis C, McCaffrey WD, et al. Hybrid sediment gravity flow deposits-classification, origin and significance. Mar Pet Geol. 2009;26:1900-18. https://doi.org/10.1016/J.MARPE TGEO.2009.02.012.

Hiscott RN. Traction-carpet stratification in turbidites fact or fiction. J Sediment Res. 1994;64:204-8. https://doi.org/10.1306/D4267 D57-2B26-11D7-8648000102C1865D.

Hodgson DM. Distribution and origin of hybrid beds in sand-rich submarine fans of the Tanqua depocentre, Karoo Basin. South Afr Mar Pet Geol. 2009;26:1940-56. https://doi.org/10.1016/J. MARPETGEO.2009.02.011.

Hofstra M, Hodgson DM, Peakall J, et al. Giant scour-fills in ancient channel-lobe transition zones: Formative processes and depositional architecture. Sediment Geol. 2015;329:98-114. https://doi. org/10.1016/J.SEDGEO.2015.09.004.

Ito M. Downfan transformation from turbidity currents to debris flows at a channel-to-lobe transitional zone: the lower Pleistocene Otadai Formation, Boso Peninsula. Jpn J Sediment Res. 2008;78(10):668-82. https://doi.org/10.2110/JSR.2008.076.

Jobe ZR, Lowe DR, Morris WR. Climbing-ripple successions in turbidite systems: depositional environments, sedimentation rates and accumulation times. Sedimentology. 2012;59:867-98. https ://doi.org/10.1111/J.1365-3091.2011.01283.X.

Kane IA, Pontén AS. Submarine transitional flow deposits in the Paleogene Gulf of Mexico. Geology. 2012;40(12):1119-22. https://doi. org/10.1130/G33410.1.

Kneller BC, Branney MJ. Sustained high-density turbidity currents and the deposition of thick massive sands. Sedimentology. 1995;42:607-16. https://doi.org/10.1111/J.1365-3091.1995. TB00395.X.

Kneller BC, Mccaffrey WD. The interpretation of vertical sequences in turbidite beds: the influence of longitudinal flow structure. J. Sed. Res. 2003;73:706-13.

Kuang L, Tang Y, Lei D, et al. Formation conditions and exploration potential of tight oil in the Permian saline lacustrine dolomitic rock, Junggar Basin. NW China Pet Exp Dev. 2012;39(6):700-11. https://doi.org/10.1016/S1876-3804(12)60095-0.

Liu J, Xian B, Wang J, et al. Sedimentary architecture of a sublacustrine debris fan: Eocene dongying depression, bohai bay basin, east china. Sediment Geol. 2017;362:66-82. https://doi. org/10.1016/j.sedgeo.2017.09.014.

Lowe DR. Sediment gravity flows: II Depositional models with special reference to the deposits of high-density turbidity currents. J Sediment Res. 1982;52:279-97. https://doi.org/10.1306/212F7 F31-2B24-11D7-8648000102C1865D. 
Lowe DR, Guy M. Slurry-flow deposits in the Britannia Formation (Lower Cretaceous), North Sea: a new perspective on the turbidity current and debris flow problem. Sedimentology. 2000;47:31-70. https://doi.org/10.1046/J.1365-3091.2000.00276.X.

Luo Q, Gong L, Qu Y, et al. The tight oil potential of the Lucaogou Formation from the southern Junggar Basin. China Fuel. 2018;234:858-71. https://doi.org/10.1016/J.FUEL.2018.07.002.

Macdonald HA, Wynn RB, Huvenne VA, et al. New insights into the morphology, fill, and remarkable longevity ( $>0.2$ my) of modern deepwater erosional scours along the northeast Atlantic margin. Geosphere. 2011;7(4):845-67. https://doi.org/10.1130/GES00 611.1.

Marr JG, Harff PA, Shanmugam G, Parker G. Experiments on subaqueous sandy gravity flows: the role of clay and water content in flow dynamics and depositional structures. Geol. Soc. Am. Bull. 2001;113:1377-86.

Mueller P, Patacci M, Di Giulio A. Hybrid event beds in the proximal to distal extensive lobe domain of the coarse-grained and sand-rich Bordighera turbidite system (NW Italy). Mar Pet Geol. 2017;86:908-31. https://doi.org/10.1016/J.MARPE TGEO.2017.06.047.

Mutti E. Distinctive thin-bedded turbidite facies and related depositional environments in the Eocene Hecho Group (South-central Pyrenees, Spain). Sedimentology. 1977;24(1):107-31. https://doi. org/10.1111/J.1365-3091.1977.TB00122.X.

Nie S, Rowley DB, Van der Voo R, et al. Paleomagnetism of Late Paleozoic rocks in the Tianshan. Northwestern China Tectonics. 1993;12(2):568-79. https://doi.org/10.1029/92TC00657.

Normark WR. Fan valleys, channels, and depositional lobes on modern submarine fans: characters for recognition of sandy turbidite environments. AAPG Bull. 1978;62(6):912-31. https://doi. org/10.1306/C1EA4F72-16C9-11D7-8645000102C1865D.

Patacci M, Haughton PDW, McCaffrey WD. Rheological complexity in sediment gravity flows forced to decelerate against a confining slope, Braux. SE France J Sediment Res. 2014;84(4):270-7. https ://doi.org/10.2110/JSR.2014.26.

Peters SE, Loss DP. Storm and fair-weather wave base: A relevant distinction? Geology. 2012;40(6):511-4. https://doi.org/10.1130/ G32791.1.

Pickering KT. The Kongsfjord Formation-a late Precambrian submarine fan in northeast Finnmark. North Norway Norges geologiske Undersøgelse. 1981a;367:77-104.

Pickering KT. Two types of outer fan lobe sequence, from the late Precambrian Kongsfjord Formation submarine fan, Finnmark. North Norway J Sediment Res. 1981b;51(4):1277-86. https:// doi.org/10.1306/212F7E87-2B24-11D7-8648000102C1865D.

Pierce CS, Haughton PD, Shannon PM, et al. Variable character and diverse origin of hybrid event beds in a sandy submarine fan system, Pennsylvanian Ross Sandstone Formation, western Ireland. Sedimentology. 2018;65(3):952-92. https://doi.org/10.1111/ sed.12412.

Piper DJW. Turbidite muds and silts on deepsea fans and abyssal plains. In: Stanley DJ, Kelling G, editors. Sedimentation in Submarine Canyons, Fans and Trenches. Hutchinson and Ross, Stroudsburg, Pennsylvania: Dowden; 1978. p. 163-76.

Piper DJ, Normark WR. Turbidite depositional patterns and flow characteristics, Navy submarine fan. California Borderland Sedimentol. 1983;30(5):681-94. https://doi. org/10.1111/J.1365-3091.1983.TB00702.X.

Pohl F, Eggenhuisen JT, Tilston M, et al. New flow relaxation mechanism explains scour fields at the end of submarine channels. Nature Commun. 2019;10(1):1-8. https://doi.org/10.1038/S4146 7-019-12389-X.

Postma G, Cartigny M, Kleverlaan K. Structureless, coarse-tail graded Bouma Ta formed by internal hydraulic jump of the turbidity current? Sediment Geol. 2009;219(1-4):1-6. https:// doi.org/10.1016/J.SEDGEO.2009.05.018.

Postma G, Cartigny MJ. Supercritical and subcritical turbidity currents and their deposits—A synthesis. Geology. 2014;42(11):987-90. https://doi.org/10.1130/G35957.1.

Prélat A, Hodgson DM, Flint SS. Evolution, architecture and hierarchy of distributary deepwater deposits: a high-resolution outcrop investigation of submarine lobe deposits from the Permian Karoo Basin. South Afr Sedimentol. 2009;56:2132-54. https://doi.org/1 0.1111/J.1365-3091.2009.01073.X.

Pyles DR, Straub KM, Stammer JG. Spatial variations in the composition of turbidites due to hydrodynamic fractionation. Geophys Res Lett. 2013;40(15):3919-23. https://doi.org/10.1002/ GRL.50767.

Reading HG, Richards M. Turbidite systems in deepwater basin margins classified by grain size and feeder system. AAPG Bull. 1994;78(5):792-822. https://doi.org/10.1306/A25FE3BF171B-11D7-8645000102C1865D.

Shan X, Shi X, Clift PD, et al. Carbon isotope and rare earth element composition of Late Quaternary sediment gravity flow deposits on the mid shelf of East China Sea: Implications for provenance and origin of hybrid event beds. Sedimentology. 2019;66:1861-95. https://doi.org/10.1111/SED.12561.

Shan X, Shi X, Qiao S, et al. The fluid mud flow deposits represent mud caps of Holocene hybrid event beds from the widest and gentlest shelf. Marine Geol. 2019;415:105959. https://doi.org/10.1016/J. MARGEO.2019.06.004.

So YS, Rhee CW, Choi, et al. Distal turbidite fan/lobe succession of the Late Paleozoic Taean Formation, western Korea. Geosciences J. 2013;17(1):9-25. https://doi.org/10.1007/S12303-013-0016-0.

Sohn YK. On traction-carpet sedimentation. J Sediment Res. 1997;67(3):502-9. https://doi.org/10.1306/D42685AE2B26-11D7-8648000102C1865D.

Southard JB. Experimental Determination of Bed-Form Stability. Annu Rev Earth Planet Sci. 1991;19:423-55. https://doi.org/10.1146/ annurev.ea.19.050191.002231.

Southern SJ, Kane IA, Warchoł MJ, et al. Hybrid event beds dominated by transitional-flow facies: character, distribution and significance in the Maastrichtian Springar Formation, north-west Vøring Basin. Norwegian Sea Sedimentol. 2017;64(3):747-76. https:// doi.org/10.1111/SED.12323.

Spychala YT, Hodgson DM, Stevenson CJ, et al. Aggradational lobe fringes: The influence of subtle intrabasinal seabed topography on sediment gravity flow processes and lobe stacking patterns. Sedimentology. 2017a;64(2):582-608. https://doi.org/10.1111/ SED.12315.

Spychala YT, Hodgson DM, Prélat A, Kane IA, Flint SS, Mountney NP. Frontal and Lateral Submarine Lobe Fringes: Comparing Sedimentary Facies, Architecture and Flow Processes. J Sediment Res. 2017b;87(1):75-96.

Stevenson CJ, Jackson CAL, Hodgson DM, et al. Deepwater sediment bypass. J Sediment Res. 2015;85(9):1058-81. https://doi. org/10.2110/JSR.2015.63.

Stow DAV, Bowen AJ. A physical model for the transport and sorting of fine-grained sediment by turbidity currents. Sedimentology. 1980;27:31-46. https://doi.org/10.1111/J.1365-3091.1980.TB011 56.X.

Su Y, Zha M, Ding X, et al. Pore type and pore size distribution of tight reservoirs in the Permian Lucaogou Formation of the Jimsar Sag, Junggar Basin. NW China Mar Pet Geol. 2018;89:761-74. https ://doi.org/10.1016/j.marpetgeo.2017.11.014.

Sumner EJ, Talling PJ, Amy LA, et al. Facies architecture of individual basin-plain turbidites: Comparison with existing models and implications for flow processes. Sedimentology. 2012;59:185087. https://doi.org/10.1111/J.1365-3091.2012.01329.X. 
Talling PJ, Amy LA, Wynn RB, et al. Beds comprising debrite sandwiched within co-genetic turbidite: origin and widespread occurrence in distal depositional environments. Sedimentology. 2004;51(1):163-94. https://doi.org/10.111 1/J.1365-3091.2004.00617.X.

Talling PJ, Masson DG, Sumner EJ, et al. Subaqueous sediment density flows: Depositional processes and deposit types. Sedimentology. 2012;59:1937-2003. https://doi.org/10.111 1/J.1365-3091.2012.01353.X.

Talling PJ, Malgesini G, Felletti F. Can liquefied debris flows deposit clean sand over large areas of sea floor? Field evidence from the Marnoso-arenacea formation. Italian Apennines Sedimentol. 2013;60(3):720-62. https://doi.org/10.111 1/J.1365-3091.2012.01358.X.

Tao S, Wang Y, Tang D, et al. Organic petrology of Fukang Permian Lucaogou Formation oil shales at the northern foot of Bogda mountain, Junggar Basin. China Int J Coal Geol. 2012;99:27-34. https://doi.org/10.1016/j.coal.2012.05.001.

Van der Merwe WC, Hodgson DM, Brunt RL, et al. Depositional architecture of sand-attached and sand-detached channel-lobe transition zones on an exhumed stepped slope mapped over a $2500 \mathrm{~km} 2$ area. Geosphere. 2014;10(6):1076-93. https://doi.org/10.1130/ GES01035.1.

Walker RG. Deepwater sandstone facies and ancient submarine fans: models for exploration for stratigraphic traps. AAPG Bull. 1978;62(6):932-66. https://doi.org/10.1306/C1EA4F77-16C911D7-8645000102C1865D.

Wang J, Cao Y, Wang X, et al. Sedimentological constraints on the initial uplift of the West Bogda Mountains in Mid-Permian. Sci Rep. 2018;8(1):1453-1453. https://doi.org/10.1038/s41598-01819856-3.
Wu H, Hu W, Cao J, et al. A unique lacustrine mixed dolomitic-clastic sequence for tight oil reservoir within the middle Permian Lucaogou Formation of the Junggar Basin, NW China: Reservoir characteristics and origin. Mar Pet Geol. 2016;76:115-32. https://doi. org/10.1016/j.marpetgeo.2016.05.007.

Xiao W, Windley B, Hao J, et al. Arc-ophiolite obduction in the Western Kunlun Range (China): implications for the Palaeozoic evolution of central Asia. J Geol Soc. 2002;159:517-28. https://doi. org/10.1144/0016-764901-093.

Yang RC, Jin ZJ, Van Loon AJ, et al. Climatic and tectonic controls of lacustrine hyperpycnite origination in the Late Triassic Ordos Basin, central China: implications for unconventional petroleum development. AAPG Bull. 2017;101(1):95-117. https://doi. org/10.1306/06101615095.

Yang T, Cao Y, Liu K, et al. Genesis and depositional model of subaqueous sediment gravity-flow deposits in a lacustrine rift basin as exemplified by the Eocene Shahejie Formation in the Jiyang Depression. Eastern China Mar Pet Geol. 2019;102:231-57. https ://doi.org/10.1016/j.marpetgeo.2018.12.033.

Zavala C, Arcuri M. Intrabasinal and extrabasinal turbidites: Origin and distinctive characteristics. Sediment Geol. 2016;337:36-54. https://doi.org/10.1016/j.sedgeo.2016.03.008.

Zhao P, Wang Z, Sun Z, et al. Investigation on the pore structure and multifractal characteristics of tight oil reservoirs using NMR measurements: Permian Lucaogou Formation in Jimusaer Sag. Junggar Basin Mar Pet Geol. 2017;86:1067-81. https://doi. org/10.1016/j.marpetgeo.2017.07.011.

Zou C, Wang L, Li Y, et al. Deep-lacustrine transformation of sandy debrites into turbidites, Upper Triassic. Central China Sediment Geol. 2012;265:143-55. https://doi.org/10.1016/j.sedge o.2012.04.004. 